\title{
A novel RNA aptamer identifies plasma membrane ATP synthase beta subunit as an early marker and therapeutic target in aggressive cancer
}

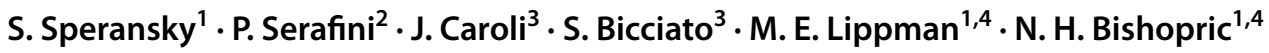

Received: 12 February 2019 / Accepted: 18 February 2019 / Published online: 20 April 2019

(c) The Author(s) 2019

\begin{abstract}
Purpose Primary breast and prostate cancers can be cured, but metastatic disease cannot. Identifying cell factors that predict metastatic potential could guide both prognosis and treatment.

Methods We used Cell-SELEX to screen an RNA aptamer library for differential binding to prostate cancer cell lines with high vs. low metastatic potential. Mass spectroscopy, immunoblot, and immunohistochemistry were used to identify and validate aptamer targets. Aptamer properties were tested in vitro, in xenograft models, and in clinical biopsies. Gene expression datasets were queried for target associations in cancer.

Results We identified a novel aptamer (Apt63) that binds to the beta subunit of $F_{1} F_{0}$ ATP synthase (ATP5B), present on the plasma membrane of certain normal and cancer cells. Apt63 bound to plasma membranes of multiple aggressive breast and prostate cell lines, but not to normal breast and prostate epithelial cells, and weakly or not at all to non-metastasizing cancer cells; binding led to rapid cell death. A single intravenous injection of Apt63 induced rapid, tumor cell-selective binding and cytotoxicity in MDA-MB-231 xenograft tumors, associated with endonuclease G nuclear translocation and DNA fragmentation. Apt63 was not toxic to non-transformed epithelial cells in vitro or adjacent normal tissue in vivo. In breast cancer tissue arrays, plasma membrane staining with Apt63 correlated with tumor stage $(p<0.0001, n=416)$ and was independent of other cancer markers. Across multiple datasets, ATP5B expression was significantly increased relative to normal tissue, and negatively correlated with metastasis-free $(p=0.0063,0.00039$, respectively) and overall $(p=0.050,0.0198)$ survival. Conclusion Ecto-ATP5B binding by Apt63 may disrupt an essential survival mechanism in a subset of tumors with high metastatic potential, and defines a novel category of cancers with potential vulnerability to ATP5B-targeted therapy. Apt63 is a unique tool for elucidating the function of surface ATP synthase, and potentially for predicting and treating metastatic breast and prostate cancer.
\end{abstract}

Keywords Ecto-ATP synthase $\cdot$ Metastasis $\cdot$ Breast cancer $\cdot$ Prostate cancer $\cdot$ Aptamer $\cdot$ Cell-SELEX

Electronic supplementary material The online version of this article (https://doi.org/10.1007/s10549-019-05174-3) contains supplementary material, which is available to authorized users.

\section{N. H. Bishopric}

nhb20@georgetown.edu

1 Department of Medicine, Sylvester Comprehensive Cancer Center, University of Miami Miller School of Medicine, Miami, USA

2 Department of Microbiology \& Immunology, Sylvester Comprehensive Cancer Center, University of Miami Miller School of Medicine, Miami, USA

3 Center for Genome Research, Department of Life Sciences, University of Modena and Reggio Emilia, Modena, Italy

4 Department of Oncology, Georgetown Lombardi Comprehensive Cancer Center, Georgetown University, Washington, DC, USA

\section{Introduction}

Localized prostate and breast cancers are highly curable, but once metastasized to remote organs, these cancers are inevitably lethal. Consequently, an important goal of treatment is to identify and exploit specific vulnerabilities of the metastatic cell. Another key aim is to predict which tumors are at high risk of metastasis, allowing potentially toxic therapy to be tailored to those most likely to benefit. These goals have been aided by an improved understanding of cancer cell genetic drift during tumor progression, which allows certain cells to acquire independence from supportive factors in the tissue of origin, to migrate into the vasculature, and to survive and grow at foreign sites such as liver and bone. In addition to genetic drivers of the metastatic phenotype 
[1-5], epigenetic and protein-level changes have been found to establish tumor cell aggressiveness, including episomal transfer of microRNAs to and from adjacent normal cells, reprogramming of the tumor or stroma by factors released from tumor-infiltrating lymphocytes, and alterations in metabolism brought about by tumor hypoxia [6-8]. Energy production from carbon sources is frequently deranged in cancer, and may be associated with changes in the epigenetic state of the cell that promote cell-autonomous increases in tumor aggression (reviewed in [8]). A thorough search for metastasis-promoting changes in the cancer cell thus necessarily extends to exploration of protein content, function, and location.

In this study, we used an unsupervised method: differential Cell-SELEX (Systematic Evolution of Ligands by EXponential enrichment), to search for proteins distinguishing metastatic from non-metastatic subclones of a single parental prostate cancer cell line, LNCaP. Owing to their unique, sequence-specific tertiary structure, single-stranded nucleic acids (either DNA or RNA) can bind to individual proteins with high specificity and affinity, comparable to those of antibodies. These oligonucleotides, known as aptamers, can be modified for stability in biological fluids, labeled with fluorescent tags, fused to other molecules, and delivered in vivo without inciting an immune response [9]. Cell-SELEX uses live cells to select aptamers that recognize cellular proteins in their native and functional state. Differential Cell-SELEX applies the same method to identify aptamers that discriminate between two cell types. The ability to screen large numbers $\left(>2^{40}\right)$ of sequences increases the likelihood of identifying rare or unique surface marker differences.

Here, we report the identification of a novel RNA aptamer (Apt63) that recognizes a plasma membrane feature that is commonly expressed by multiple aggressive prostate and breast cancer cell lines and tumors, but that exhibits low expression or is absent in non-transformed cells and normal tissues. We demonstrate that the aptamer target is the beta subunit of $\mathrm{F}_{1} \mathrm{~F}_{0}$ ATP synthase (ATP5B). This protein is a catalytic component of the final enzyme in cellular ATP production by oxidative phosphorylation, and is located on the inner mitochondrial membrane. ATP5B and other components of the $\mathrm{F}_{1} \mathrm{~F}_{\mathrm{o}}$ ATP synthase complex have previously been identified on the plasma membrane of certain cell and tumor types, where it is referred to as "ecto-ATP synthase"; several studies have shown that the complex is catalytically active in extracellular ATP production [10, 11]. Various roles have been established for this activity in a few normal cell types, and particularly in angiogenesis, but its significance and function in cancer remain uncertain. Ecto-ATP synthase acts as a ligand for angiostatin and transduces some of its anti-proliferative and anti-angiogenic effects [12]. Binding to ecto-ATP synthase by angiostatin, membrane-impermeable small molecules and monoclonal antibodies against the ATP5 beta subunit have been shown to promote cell death in a wide range of susceptible cell types, including HeLa, Leishmania, and plant cells ([13] and citations therein; [14-16]). Several studies have linked expression of surface ATP synthase to more-aggressive and later-stage cancer $[17,18]$, suggesting that the activity of this complex on the cell surface may support the survival of these aggressive cells during the transition to metastasis. In this study, we show that Apt63 distinguishes aggressive breast and prostate cancer cell lines from less-aggressive congenic lines, and from non-transformed cells, both human and murine. In vivo, Apt63 binds selectively to ecto-ATP5Bexpressing tumors and not to normal adjacent tissue. Functionally, binding of Apt63 to the plasma membrane exerts selective tumor cell killing by inducing translocation of endonuclease $\mathrm{G}$ from mitochondria to nucleus, DNA fragmentation, and apoptosis. We show that that Apt63 plasma membrane binding in clinical tissue biopsies is strongly correlated with advanced tumor stage, and as a corollary, that ATP5B expression in primary tumors is predictive of poor metastasis-free and overall survival. We propose that Apt63 may be useful in early recognition and treatment of a novel subset of highly aggressive primary breast and prostate cancers, defined by surface expression of ATP5B.

\section{Materials and methods}

\section{Cell lines and cell culture}

Human prostate cancer cell lines used in the Cell-SELEX screen were obtained from Dr. Curtis Pettaway [19]. Human prostate cancer cells (PC-3, PC3-ML, RWPE-1) were generously provided by Dr. Kerry Burnstein (University of Miami)' and human breast cancer cell lines (MDA-MB-231, MDA-MB-436, MCF7, MCF10) were obtained from ATCC (Manassas, VA), Murine breast cancer cells lines (4T1, 67NR, E0771, E0771.LMB) were the gift of Dr. Barry Hudson (University of Miami). Dissociated primary tumor lines DT28 and DT22 were the generous gift of Dr. D. ElAshry (University of Minnesota) [20]. All cell lines were maintained using the suppliers' protocols and maintained in $37{ }^{\circ} \mathrm{C}, 5 \% \mathrm{CO}_{2}$ tissue culture incubators. All cell lines were routinely tested for mycoplasma using the MycoAlert Mycoplasma Detection Kit (Lonza, Walkersville, MD, USA) and an established PCR protocol [21].

\section{Differential Cell-SELEX}

The pool of RNA aptamers used for Cell-SELEX was obtained from a cDNA library with the general template: TCT CGG ATC CTC AGC GAG TCG TCT G-(N40)-CCG 
CAT CGT CCT CCC TA (where N40 represents 40 random nucleotides). The cDNA library was amplified by PCR and transcribed in vitro using a Durascribe T7 RNA synthesis kit (Lucigene, USA) with nuclease-stable 2'-F-dCTP and 2'-FdUTP as previously described [22]. The aptamer library was purified using an RNeasy kit (Qiagen). Both parental and LNCaP-Pro5 (Pro5) cells were used for negative selection, and LNCaP-LN3 (LN3) for positive selection. Each CellSELEX cycle consists two rounds of selection, negative and positive. Parental LNCaP cells were used in the first three selection cycles and Pro5 cells in cycles 4-11. At the beginning of each cycle, $1 \mu \mathrm{g}$ of the aptamer library was added to $450 \mu \mathrm{L}$ of PBS containing $0.5 \mathrm{mM} \mathrm{MgCl} 2$ and $1 \mathrm{mM} \mathrm{CaCl}_{2}$ (binding buffer) and RNA was refolded by heating $5 \mathrm{~min}$ at $67^{\circ} \mathrm{C}$ and cooling at room temperature (RT) for $10 \mathrm{~min}$. All cells used in Cell-SELEX were grown in 75T culture flasks with filtered cups (ThermoFisher Scientific). At $75 \%$ confluency, cells were briefly washed with PBS and dissociated from the flask by incubation with $3 \mathrm{ml}$ of Trypsin-EDTA $(0.25 \%)$ without phenol red (ThermoFisher Scientific) in RT for 3 min. $10 \mathrm{ml}$ of growing media was added to halt Trypsin-EDTA reaction. Detached cells were collected into $15 \mathrm{ml}$ conical tubes (Falcon) and centrifuged for $5 \mathrm{~min}$ in a $4{ }^{\circ} \mathrm{C}$ tabletop centrifuge (Eppendorf) at $600 \times g$. Cell pellets were resuspended in $5 \mathrm{ml}$ of binding buffer and counted. $2 \times 10^{5}$ Pro5 cells were separated into fresh tubes and centrifuged in tabletop centrifuge for $5 \mathrm{~min}$ at RT; the cell pellet was then resuspended with the aptamer library and incubated for $10 \mathrm{~min}$ at RT on a circular rotator to continuously agitate the cells. Cells were again centrifuged for $5 \mathrm{~min}$ at RT, and the supernatant, containing aptamers not bound to the negative selector, was collected and filtered by passing through $0.2 \mu \mathrm{m}$ Pall Acrodisc ${ }^{\circledR}$ Sterile Syringe Filters with Supor ${ }^{\circledR}$ Membrane (Pall Laboratory). In the positive selection step, $0.5 \times 10^{5} \mathrm{LN} 3$ cells were first incubated for $10 \mathrm{~min}$ at RT with $0.1 \mathrm{mg} / \mathrm{ml}$ of yeast tRNA (Sigma) to reduce nonspecific RNA binding, then LN3 cells were washed with binding buffer, centrifuged, and the cell pellet resuspended with the filtered supernatant from the negative selection. LN3 cells were incubated for $10 \mathrm{~min}$ on a rotator at RT, followed by isolation of total RNA (including bound aptamers) using Trizol reagent (Invitrogen). RNA aptamers were transcribed from total RNA using an aptamer-specific forward primer and a SuperScript ${ }^{\circledR}$ III Reverse Transcriptase reaction (Invitrogen), and amplified from first strand cDNA by standard PCR $\left(95^{\circ} \mathrm{C}, 5^{\prime}, 3 \times\left(94^{\circ} \mathrm{C} 30^{\prime \prime}, 52^{\circ} \mathrm{C} 20^{\prime \prime}, 72^{\circ} \mathrm{C}\right.\right.$ $\left.\left.25^{\prime \prime}\right), 15 \times\left(94{ }^{\circ} \mathrm{C} 30^{\prime \prime}, 54^{\circ} \mathrm{C} 20^{\prime \prime}, 72^{\circ} \mathrm{C} 25^{\prime \prime}\right), 72^{\circ} \mathrm{C} 5\right)$. RNA sequences were transcribed from the resulting cDNA pool using a Durascribe T7 kit as detailed above, and entered into the next Cell-SELEX cycle. RNA aptamer pools were sampled at cycles 1,4 , and 11 . After cycle 11, aptamer pools were sequenced, aligned, and analyzed to select candidates for further study as previously described [22, 23].
Generation of aptamers and scrambled sequences for in vitro and in vivo experiments

Selected aptamers and scrambled oligomers were synthesized by Integrated DNA Technologies (IDT, USA) and used as templates for amplification by PCR $\left(95^{\circ} \mathrm{C}, 5^{\prime}\right.$, $3 \times\left(94^{\circ} \mathrm{C} 30^{\prime \prime}, 52^{\circ} \mathrm{C} 20^{\prime \prime}, 72^{\circ} \mathrm{C} 25^{\prime \prime}\right), 15 \times\left(94^{\circ} \mathrm{C} 30^{\prime \prime}\right.$, $\left.54{ }^{\circ} \mathrm{C} 20^{\prime \prime}, 72^{\circ} \mathrm{C} 25^{\prime \prime}\right), 72{ }^{\circ} \mathrm{C} 5^{\prime}$ ) with the universal forward primer $5^{\prime}$-GGG GGA ATT CTA ATA CGA CTC ACT ATA GGG AGG ACG ATG CGG-3, and the reverse primer 5'-TCT CGG ATC CTC AGC GAG TCG TC-3' (oligomer sequences are listed in Online Resource 1). RNA sequences were then transcribed by Durascribe T7 kit (Lucigene, USA) following the manufacturer's protocol. RNA aptamers and scrambled sequences were labeled for in vitro experiments using Silencer ${ }^{\mathrm{TM}}$ siRNA Labeling Kit with $\mathrm{Cy}^{\mathrm{TM}} 3$ dye (Thermo Fisher Scientific) and for in vivo experiments using Ulysis Alexa Fluor ${ }^{\mathrm{TM}} 647$ Nucleic Acid Labeling Kit (Thermo Fisher Scientific) following the manufacturer's recommended protocols.

\section{Fluorescence microscopy for aptamer imaging}

Cells were seeded into $35 \mathrm{~mm}$ glass bottom dishes (MatTek Corporation, Ashland, MA) at a density of $0.3 \times 10^{6}$ cells per dish, and allowed to grow for $48 \mathrm{~h}$ to $60-75 \%$ confluence. Cy3-labeled aptamers were added to culture media at a final concentration of $1 \mathrm{nM}$ and incubated with live cells for $30 \mathrm{~min}$ in $37{ }^{\circ} \mathrm{C}$ in $5 \% \mathrm{CO}_{2}$. Following incubation, cells were washed $3 \times$ for 5 min each with PBS and fixed 10 min with $4 \%$ paraformaldehyde at RT. After fixation, cells were washed with PBS and counterstained with DAPI (Sigma), $1 \mu \mathrm{g}$ final concentration for $5 \mathrm{~min}$. To identify membrane co-localization of Cy3-Apt63 and ATP5B antibody, cells were grown on coverslips in $35 \mathrm{~mm}$ tissue culture dishes, and stained sequentially with Cy3-Apt63 and AlexaFluor ${ }^{\circledR} 647$ anti-ATP5B antibodies (ab223436, ABCAM), without a permeabilization step. To co-localize Apt63 and ATP5B antibody within mitochondria, cells were treated with $0.05 \%$ Triton $\mathrm{X}-100$ for $5 \mathrm{~min}$, washed three times with PBS, then incubated with both the AlexaFluor ${ }^{\circledR} 647$ anti-ATP5B antibody and Cy3-Apt63. Finally, cells were counterstained with DAPI. For some experiments, live cells were first stained with Cy3-Apt63, followed by fixation, treatment with $0.05 \%$ Triton X-100, and DAPI counterstaining as described above. Coverslips were mounted with ProLong ${ }^{\circledR}$ Gold antifade reagent (Life Technologies). Fluorescent images were obtained on a confocal microscope (Leica SP5) using a 20x dry objective (Leica PL APO CS). 


\section{Aptamer target purification and identification}

Apt63 and scrambled sequence (AptScr) were $3^{\prime}$ end-biotinylated using Pierce ${ }^{\mathrm{TM}}$ RNA 3' End Desthiobiotinylation Kit (ThermoFisher Scientific, USA) following the manufacturer's protocol. LNCaP-LN3 and LNCaP-Pro5 cells were each seeded into $100 \mathrm{~mm}$ Petri dishes for $48 \mathrm{~h}$ at a density $0.5 \times 10^{6}$ cells per dish and allowed to grow to $60-75 \%$ confluency. On the day of the experiment, cells were incubated at RT for $1 \mathrm{~h}$ with the desthiobiotin-RNAApt63 or -AptScr complexes, allowing aptamer to bind to target. Following binding, cells were washed $3 \times$ for 5 min each in PBS at RT to remove excess unbound RNAdesthiobiotin complexes, and cross-linked by incubation with $1 \%$ paraformaldehyde for $2 \mathrm{~min}$. Next, cells were thoroughly washed $3 \times$ for 5 min each in PBS at RT. To separate membranes from intracellular components, cells were incubated in a mild hypotonic lysis buffer containing $1 \mathrm{M}$ Tris- $\mathrm{HCl}, 5 \mathrm{M} \mathrm{NaCl}, 50 \mathrm{mM} \mathrm{MgCl}, 0.1 \mathrm{M}$ DTT, and protease inhibitor cocktail for $2 \mathrm{~min}$ on ice. Immediately following incubation, cells were gently homogenized in a Dounce homogenizer, ten times on ice, mixed with magnetic beads and left overnight at $4{ }^{\circ} \mathrm{C}$ to allow capture of the desthiobiotin-aptamer-target hybrid complexes. On the next day, the beads were thoroughly washed with reagents provided in the kit, and target-aptamer complexes eluted with $30 \mu \mathrm{L}$ of $8 \mathrm{M}$ urea for $10 \mathrm{~min}$ at $60{ }^{\circ} \mathrm{C}$. The recovered eluates and total cell lysate were separated on 4-20\% gradient SDS-PAGE gels (Bio-Rad, USA). Gels were stained using Pierce ${ }^{\mathrm{TM}}$ Silver Stain kits. Protein band distributions were compared between LNCaP-LN3 and LNCaP-Pro5 cell lines, and the most enriched band in the LN3 aptamertarget eluate was cut, sequenced by microcapillary LS/MS/ MS, and analyzed by SEQUEST software at Taplin Mass Spectrometry Facility (Harvard Medical School, Boston MA). The predicted protein target was verified by $4-20 \%$ gradient SDS-PAGE gel electrophoresis and western blot in whole cell lysates and aptamer eluates using ATP5B antibodies (ab170947, ABCAM) with ATP5B recombinant protein as a positive control (ab92235, ABCAM).

\section{In vitro aptamer binding affinity and cytotoxicity assays}

We used two independent methods to evaluate Apt63 cytotoxicity in a series of cell lines in vitro: (1) direct visualization of Apt63 cytotoxicity using the IncuCyte ${ }^{\circledR}$ S3 Live-Cell Analysis System, and (2) SYTOX ${ }^{\mathrm{TM}}$ Green uptake. Binding affinity of Apt63 to its membrane target was measured using the CellTiter-Gloß system (Promega). Detailed procedures are described in Online Resource 2.
Mouse xenograft models and aptamer cytotoxicity in vivo

All animal experiments were approved by and performed in accordance with the guidelines of the University of Miami Institutional Animal Care and Use Committee. For live visualization of Apt63 tumor uptake and retention in vivo, a prostate xenograft tumor model was used. NOD.CB17Prkdcscid/J male mice (10 weeks old, $n=14$, The Jackson Laboratory) were injected orthotopically into the right anterior lobe of the prostate with $2 \times 10^{6} \mathrm{LN} 3$ and $2 \times 10^{6}$ Pro5 cells. For Apt 63 cytotoxicity in vivo, we used a previously described breast tumor xenograft mouse model [24]. NOD. CB17-Prkdcscid/J female mice (6-8 weeks old, $n=39$, The Jackson Laboratory) were injected with $10^{6}$ of MDAMB-231 cells into the mammary fat pad. In both xenograft models, when tumors were palpable, $1 \mathrm{nmol}$ of Alexa Fluor $^{\mathrm{TM}}$ 647-labeled Apt63, AptScr, or unlabeled oligonucleotides suspended in $200 \mu \mathrm{L}$ of PBS was injected into the tail vein as a single injection. Mice were imaged and euthanized at specified time points. Tumors and selected tissues were dissected and processed for further analysis. Detailed procedures are described in Online Resource 2.

\section{Tumor tissue and FFPE human biopsy arrays fluorescent staining and analysis}

Xenograft tumors were removed from euthanized mice and immediately frozen or fixed with $10 \%$ buffered formalin (VWR, USA), paraffin embedded, and processed. Prostate and breast core tissue microarrays (TMA) were purchased from US Biomax, Inc (Rockville, MD). The detailed staining protocols are provided in as described in Online Resource 2. Cy3-Apt63-stained human breast biopsy microarrays were imaged by fluorescence microscopy on a Virtual Slide Microscope (VS120) for overview images and on a confocal microscope (Leica SP5) for high-resolution images, and scored for visual presence or absence (greater or less than $10 \%$ of cells, respectively) of Apt63 membrane-specific labeling. A list of TMAs with patient information, tumor grade, and stage used in this study and assigned Apt63 score for each biopsy is provided in Online Resource 3. Statistical analysis was performed for the Pearson correlation coefficient of aptamer membrane-specific stain vs. histopathological grades and stages.

\section{ATP5B expression datasets and analysis}

ATP5B gene expression was analyzed in prostate and breast cancer samples downloaded from Gene Expression Omnibus and from the Genomic Data Commons Portal. Specifically, RNA-seq data in FPKM (Fragments Per Kilobase Million) and clinical information of the TCGA Prostate 
Adenocarcinoma dataset (TCGA-PRAD [25]) were downloaded from the Genomic Data Commons Portal using functions of the TCGAbiolinks $\mathrm{R}$ package and used as is. Expression levels of prostate tumors $(n=264)$ and normal prostate tissue samples $(n=160)$ from Penney et al. [26] were downloaded from GEO GSE62872 as Series Matrix File and used as is. Raw data of 545 formalin-fixed paraffinembedded (FFPE) tissue samples from primary prostate cancer were downloaded from GEO GSE46691 [27]. Probelevel signals were converted to expression values from CEL files using robust multi-array average procedure RMA [28] and an Entrez gene-centered custom CDF for Affymetrix Human Exon 1.0 ST Array (http://brainarray.mbni.med. umich.edu/Brainarray/Database/CustomCDF/CDF_downl oad.asp; version 22). Gene expression profiles of 25 matched normal and tumor breast tissues were downloaded from GEO GSE109169 [29] as Series Matrix File and used as is. Full expression median-centered data, consisting of 522 primary tumors, 3 metastatic tumors, and 22 tumor-adjacent normal samples, and clinical information of the TCGA Breast Invasive Carcinoma dataset (TCGA-BRCA;[30]) were downloaded from https://tcga-data.nci.nih.gov/docs/ publications/brca_2012/ and used as is. Finally, we used a breast cancer compendium created from a collection of 4640 samples from 27 major datasets containing microarray data on breast cancer samples annotated with clinical information. The compendium consists of a meta-dataset of gene expression data for 3,661 unique samples from 25 independent cohorts [31,32].

All data analyses were performed in $\mathrm{R}$ (version 3.5.1) using Bioconductor libraries (BioC 3.7) and R statistical packages. To identify two groups of tumors with either high or low ATP5B expression, we used the classifier described in [33], based on the standardized expression (score) of a gene or a signature. Tumors were classified as ATP5B 'Low' if the ATP5B score was negative and as ATP5B 'High' if the ATP5B score was positive. To evaluate the prognostic value of the ATP5B score, we used the Kaplan-Meier method to estimate the probability of metastasis-free survival. To confirm these findings, the Kaplan-Meier curves were compared using the log-rank (Mantel-Cox) test. P-values were calculated according to the standard normal asymptotic distribution, using a cutoff of 0.05 for significance. Survival analysis was performed in GraphPad Prism.

\section{Results}

\section{Identification of an aptamer recognizing aggressive cancer}

As an initial approach to discovering features of cancers with high metastatic risk, we performed differential Cell-SELEX comparing two subclones of a single prostate cancer line (LNCaP) with divergent metastatic potential. Parental LNCaP and Pro5 variant lines, which are poorly metastatic, were used for library subtraction, while the aggressive LN3 line was used for positive screening. 11 cycles of negative and positive selection were performed (Fig. 1a). Ongoing enrichment of high-affinity LN3-specific aptamers was monitored by SYBR ${ }^{\circledR}$ Green fluorescence as an indicator of annealing. Figure $1 \mathrm{~b}$ shows RoT curve analyses at each cycle, demonstrating a progressive increase in binding affinity and decreasing the complexity of aptamers as selection progress. Aptamer pools were sampled at cycles $0,1,4$, and 11 and sequenced. Sequences showing a frequency higher than $1 / 10^{6}$ in the last analyzed cycle (i.e., cycle 11 ) were selected for further investigation. After this filtering step, 691 unique sequences were clustered into families using Clustal Omega software [34] (Fig. 1c), and representative aptamers from each of 5 selected families were selected for further testing.

The selected RNA aptamers, together with scrambled controls, were labeled with $\mathrm{Cy} 3$ and incubated with live LN3 and Pro5 cells. Aptamers \#63 and \#41 showed strong binding to LN3, while only background fluorescence was seen with the other aptamers and control sequences (Fig. 1d and Online Resource 4). Pro5 cells were not bound by either aptamer or by scrambled controls (Fig. 1d and Online Resource 4). Because of the greater intensity of Apt63 fluorescence, this sequence was chosen for further testing.

We next asked whether Apt63 would preferentially interact with other highly metastatic cell lines derived from other tissues, including human prostate, human breast, and murine breast cancers. Non-tumorigenic and poorly metastatic cell lines were used for comparison (Fig. 2). As with LN3, the aggressive prostate cancer cell lines PC-3 and PC3-ML were strongly labeled by Apt63, while the non-tumorigenic prostate epithelial cell line RWPE-1 was not (Fig. 2a). The readily metastasizing MDA-MB-231 and MDA-MB-436 breast cancer cell lines were also strongly labeled by Apt63, but the non-tumorigenic breast epithelial cell line MCF10A was not labeled, and the poorly metastasizing MCF-7 line was weakly bound by Apt63. The primary dissociated breast tumor line DT28, which metastasizes efficiently, was strongly labeled by Apt63, but the non-metastasizing DT22 line was not [35]. Apt63 also efficiently discriminated between murine breast cancer cell lines with different metastatic potentials (Online Resource 5), indicating inter-species conservation of the binding target. Live cells stained with Apt63 showed a punctate pattern that appeared to be concentrated at the plasma membrane, with some variation in labeling intensity (Fig. 2a, b). These findings suggest that the target recognized by Apt63 is located on the cell surface and is a common feature among cell lines with high metastatic potential. 


\section{a}

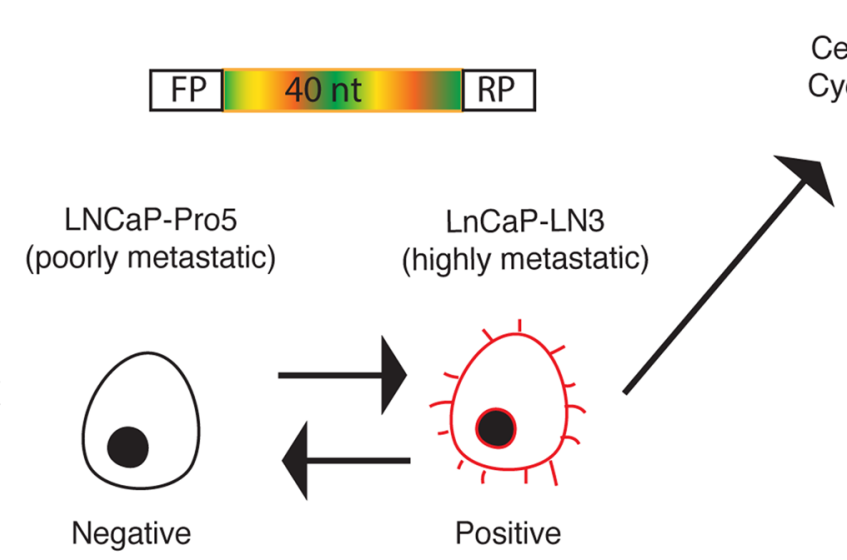
Bound oligomers
amplified

\section{Cell-SELEX \\ Cycles \#2-11}
Bound oligomers
discarded

\section{Cell-SELEX Cycle \#1}

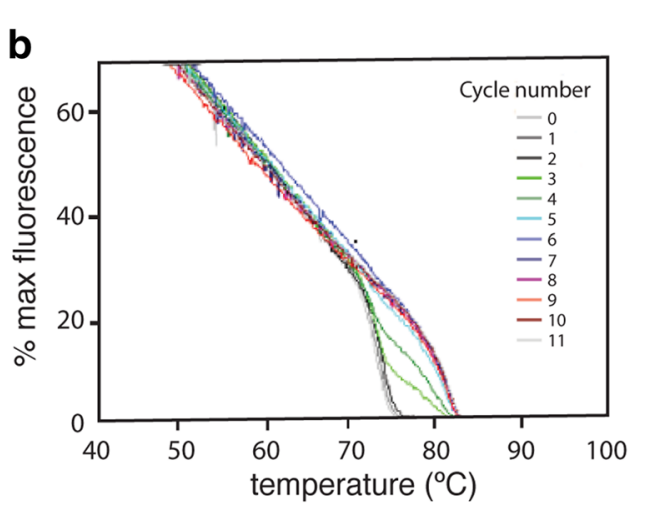

d

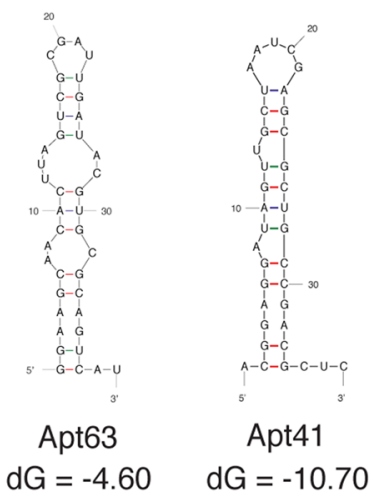

C

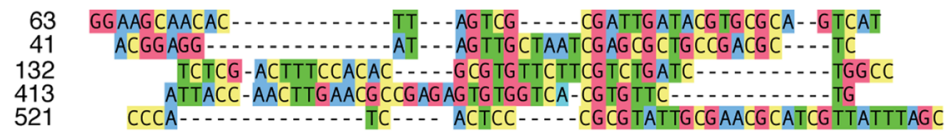

e
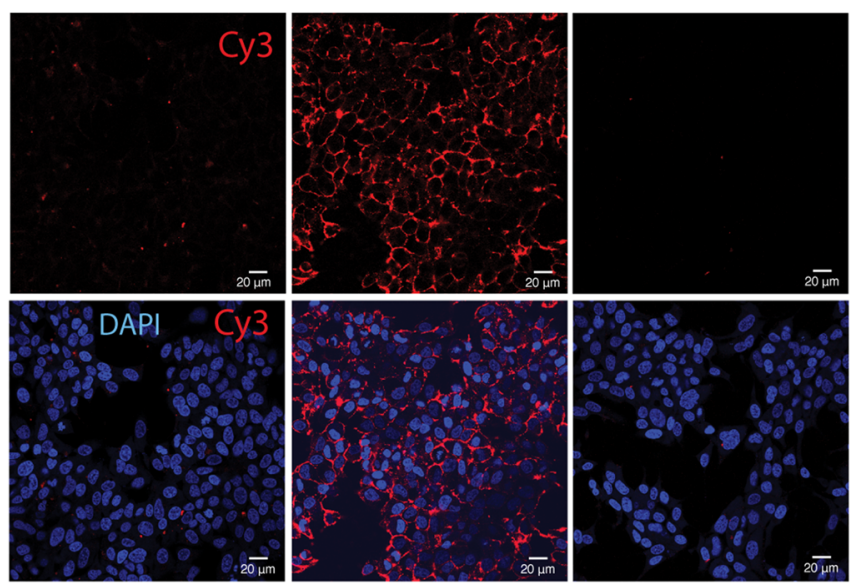

LN3

LN3

Scrambled

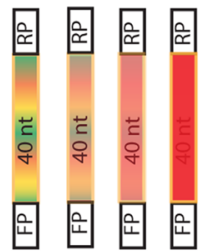

$\begin{array}{llll}0 & 1 & 4 & 11\end{array}$

Cycles sampled for RNASEq

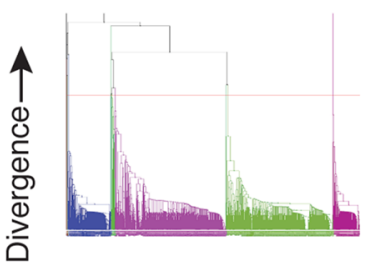

Sequence families enriched in Cycle 11
Fig. 1 Identification of Aptamer 63 (Apt63) by differential CellSELEX. a Schematic of the Cell-SELEX screening process (top). Representation of the RNA molecules library featuring a central 40 random nucleotides (multicolor), flanked by forward (FP) and reverse (RP) primer sequences. The library was screened for differential binding to surface feature(s) unique to LNCaP-LN3 prostate cancer cells. Negative selection was performed using poorly metastatic LNCaPPro5 cells (smooth black) and positive selection was performed on the highly metastasis-prone LN3 subclone (spiky red). Sequential negative and positive selection cycles enrich the aptamer pool for LN-binding sequences (top right). RNA aptamer pools were sampled after cycles 1, 4, and 11 and sequenced. Sequences enriched at cycle
11 relative to earlier cycles were aligned and clustered (bottom right). b RoT curve analyses for cycles $0-11$. Progressive increase in binding affinity is seen as the complexity of the aptamer pool decreases. Enrichment for high-affinity binding is detectable as early as cycle 3. c Alignment of 5 sequences from (a) that was tested for selective in vitro binding to LN3 cells. d The secondary structure of 2 aptamer sequences showing selective binding to LN3 vs. Pro5 cells was determined using mFold Web Server (The RNA Institute, University at Albany, State University of New York). e Representative confocal images of LN3 and Pro5 cells bound by Cy3-labeled Apt63 or AptScr. (Color figure online) 


\section{Apt63 binding is selectively cytotoxic to cancer cells in culture and in vivo}

We speculated that the target of Apt63 on LN3 cells might be functionally important in promoting its metastatic phenotype, possibly as a survival factor, and that binding by the aptamer might impair this function. Accordingly, we tested for direct Apt63 cytotoxicity in vitro, using two methods. First, real-time cytotoxicity was monitored in Apt63exposed LN3 cells by SYTOX® Green uptake and fluorescence, using an IncuCyte ${ }^{\circledR}$ S3 Live-Cell Analysis System. The SYTOX® Green nucleic acid dye is excluded by healthy cells with normal membrane permeability but diffuses passively through damaged membranes. After addition of Apt63 or a scrambled aptamer (AptScr), together with SYTOX® Green, fluorescent images were recorded every $5 \mathrm{~min}$ for the duration of the experiment (Fig. 3a; see also the time-lapse video in Online Resource 6). No difference in cell death was seen among the various conditions at $20 \mathrm{~min}$ (Fig. 3a). By
100 min, most LN3 cells exposed to Apt63 were brightly fluorescent, indicating cytotoxicity, but there was no change in ongoing basal death rates of Pro5 or AptScr-treated LN3 cells (Fig. 3a). These findings suggest that Apt63 induces rapid cell death upon engagement of an LN3-enriched epitope, leading to membrane compromise and cell death within $2 \mathrm{~h}$. Next, we estimated the dose dependence of Apt63 cytotoxicity in LN3 cells using ATP content as an indicator of cell viability. Cells were exposed to a range of concentrations of Apt63 and media ATP fluorescence determined using a CellTiter-Glo ${ }^{\circledR}$ system as described in "Materials and methods." A relatively sharp decrease in cell viability is observed at an approximate IC50 $=1.030 \mathrm{nM}\left(R^{2}=0.9497\right.$, Fig. 3b). For comparison, the IC50 for angiostatin in this assay was $1.66 \mu \mathrm{M}\left(R^{2}=0.884\right.$. Fig. $\left.3 b\right)$.

To determine whether Apt63 binding and cytotoxicity were correlated in other cell lines, we grew human PC3, PC3ML, RWPE, MDA-MB-231, MDA-MB-436, MCF7, MCF10A, and mouse T41 and NR 67 cell lines, along with

a
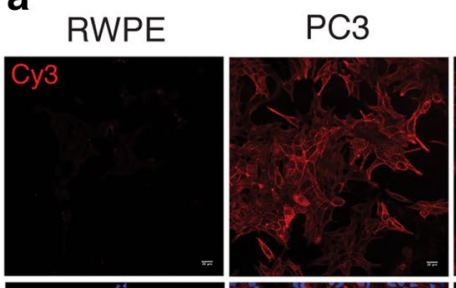

PC3-ML
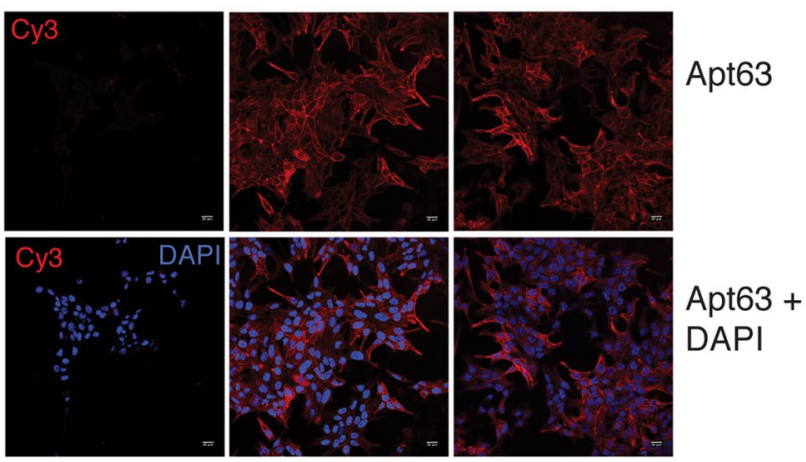

b
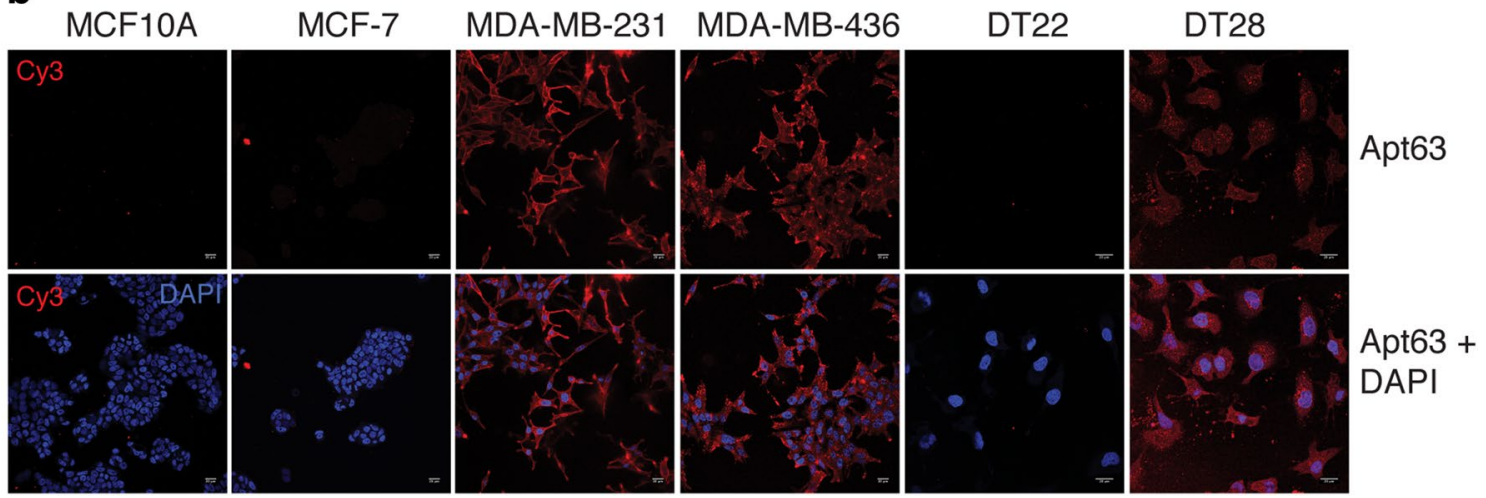

Fig. 2 Discriminative staining of aggressive breast cancer by Aptamer 63. The indicated cancer cell lines in live in culture were incubated with $1 \mathrm{nmol}$ of Cy3-labeled Apt63 (top) or a AptScr (below). a Aggressive PC-3 and PC-ML show positive staining by Apt63; prostate epithelial cell line RWPE does not show positive staining. b Weakly metastatic MCF-7, aggressive MDA-MB-231 and

MDA-MB-436 breast cancer cell lines, and aggressive DT28 dissociated tumor line show membrane-specific staining; a non-tumorforming breast epithelial cell line MCF10A and non-metastatic DT22 tumor line do not have positive staining. Original confocal imaging magnification: $\times 20$. (Color figure online) 

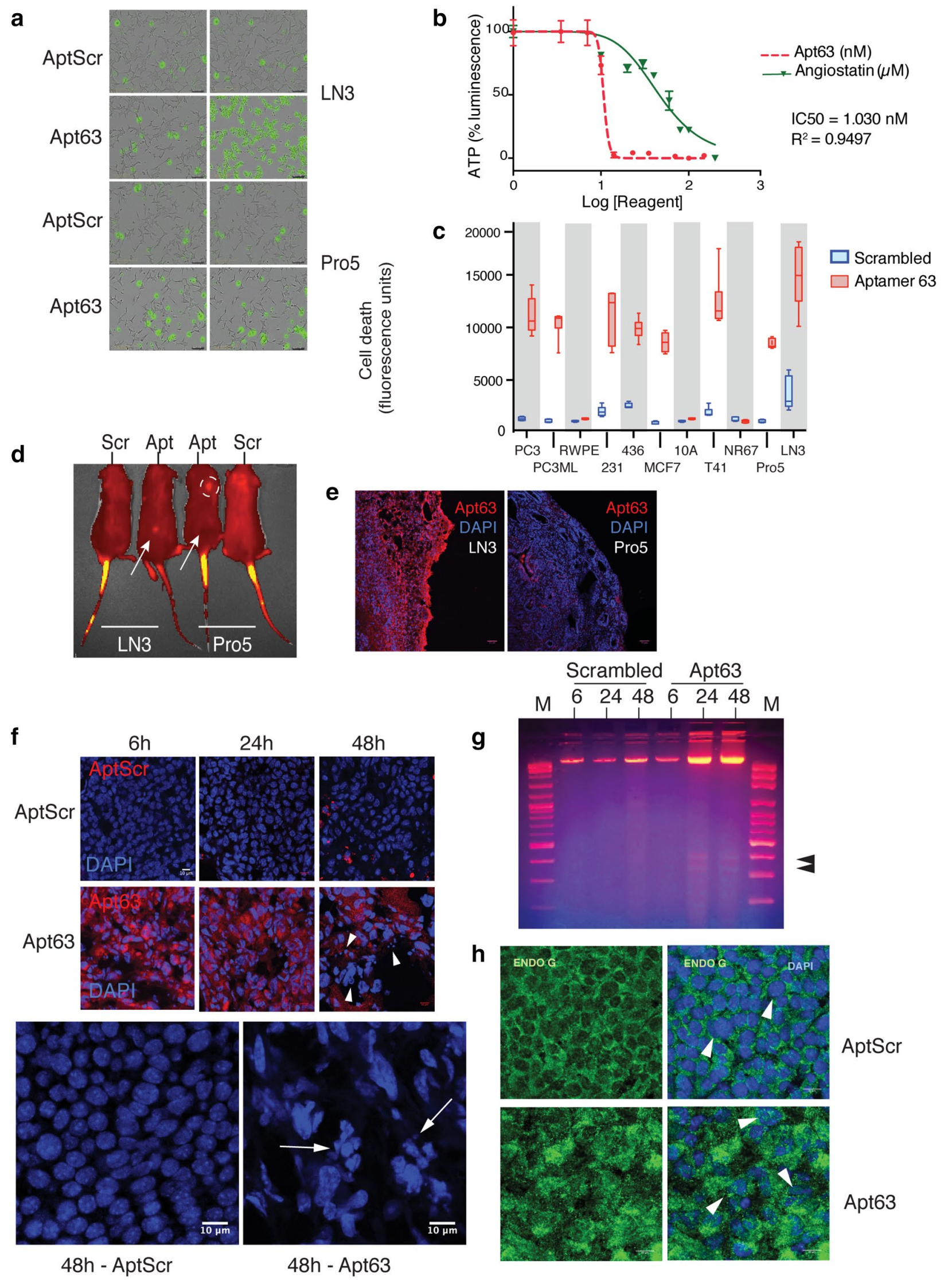

g
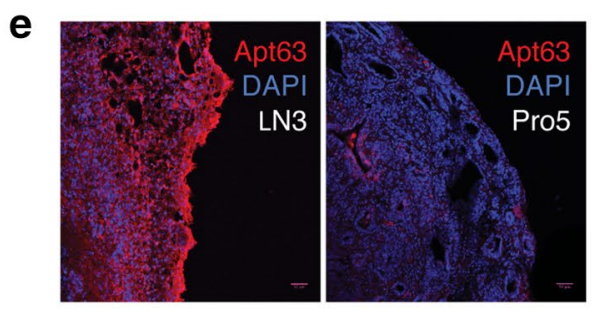

Scrambled Apt63

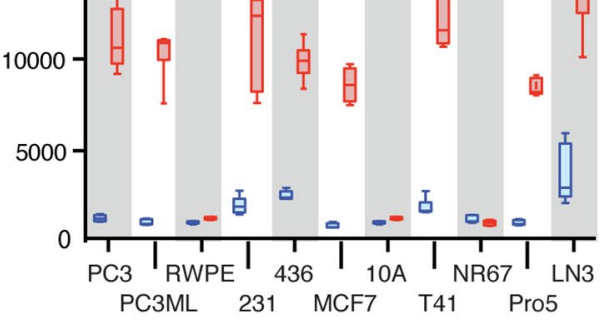

$\square$ Aptamer 63 
4Fig. 3 Apt63 binding is selectively cytotoxic to cancer cells in culture and in vivo. a Rapid in vitro cytotoxicity induced by Apt63. Cell death was monitored in real time by SYTOX® Green fluorescence as described in "Materials and methods." Representative photographs after $10 \mathrm{~min}$ (left column), and after 2-h post-treatment (right column). Original magnification: $\times 20$. b Concentration dependence of Apt63 cytotoxicity. Apt63 (unlabeled) or angiostatin was added to the cells at the indicated concentrations and luciferin luminescence was measured at $2 \mathrm{~h}$ in an EnVision ${ }^{\mathrm{TM}}$ plate reader. Readings were normalized to untreated cells and plotted using GraphPad Prism 8 Software. Apt63 IC50=1.030 nM. IC50 for angiostatin $=1.66$ micromolar ( $>10^{3} \times$ higher). c Cell selectivity of Apt63 cytotoxicity. The indicated cell lines were incubated with Apt63 or a scrambled aptamer (AptScr) in the presence of SYTOX ${ }^{\circledR}$ Green. Y-axis indicates absolute fluorescence units at $3 \mathrm{~h}$. d, e Selective Apt63 uptake by LN3 xenograft tumors after intravenous injection in vivo. LN3 and Pro5 orthotopic tumor xenografts were established in mice as described in "Materials and methods," and Alexa Fluor 647-labeled Apt63 or AptScr was injected via tail vein. d Representative in vivo images, $3.5 \mathrm{~h}$ post injection on an IVIS Spectrum in vivo imaging system (Perkin Elmer). Arrows indicate the position of xenograft tumors in Apt63-injected mice; circle indicates site of a lung abscess identified postmortem. e. Selective uptake of Apt63 by LN3 cells. Frozen sections of tumors removed from animals $4 \mathrm{~h}$ after delivery of labeled aptamer were counterstained with DAPI. Representative fluorescence images are shown. f Apt63 binds to and induces nuclear fragmentation in MDA-MB-231 breast xenograft tumors in vivo. Orthotopic MDA-MB-231 xenografts were established as described in "Materials and methods." Mice received a single injection of $1 \mathrm{nmol}$ Apt63 by tail vein as in (d), above, and were euthanized 6, 24, $48 \mathrm{~h}$ later. Xenograft frozen sections were prepared as in (e). Representative images AptScr- (top) and Apt63- (center) labeled tumors at each time point. Note retention of fluorescent label and increased nuclear fragmentation in Apt63-exposed xenografts (arrowheads). (Bottom) Enlarged images showing DAPI-stained xenograft tumors at $48 \mathrm{~h}$ after injection of AptScr and Apt63. Arrows point to fragmented MDA-MB-231 nuclei in Apt63-exposed tumors. g Nucleosomal cleavage pattern in Apt63-treated cells. DNA fragmentation in Apt63-treated tumors was confirmed by electrophoresis of total genomic DNA. Electrophoresis of tumor DNA shows accumulation of 300-400 bp DNA cleavage products (arrowheads). h Apt63 induces EndoG translocation from mitochondria to nuclei. Xenograft frozen sections at $24 \mathrm{~h}$ were stained with rabbit polyclonal EndoG antibody (ab9647, ABCAM) and counterstained with DAPI. (Color figure online)

the original LN3 and Pro5 cell lines, in 96-well plates for $24 \mathrm{~h}$. Each cell line was treated with unlabeled $1 \mathrm{nM}$ of Apt63 and $5 \mathrm{nM}$ SYTOX ${ }^{\circledR}$ Green dye for $3 \mathrm{~h}$. Binding of Apt63 to live cells in culture correlated closely with rapid cytotoxicity as shown by SYTOX® Green fluorescence (Fig. 3c, red bars; compare Fig. 2a). No cell death was seen with AptScr (blue bars). Non-tumorigenic epithelial cell lines RWPE and MCF10A, which do not bind Apt63, were completely resistant, while cell lines with weak staining had correspondingly reduced susceptibility (e.g., MCF-7) (Fig. 3c). The residual toxicity of Apt63 in these weakly staining cells could reflect the presence of small subpopulations of vulnerable cells. Overall, however, these findings suggest that Apt63 cytotoxicity is sequence-specific and dependent on the presence of a specific epitope found on multiple cancer cell types.
We then asked whether Apt63 could exert sequence-specific binding and toxicity for cells grown as xenograft tumors in vivo. In initial experiments, we tested whether LN3 and Pro5 tumor cells would differentially take up Apt63 after intravenous injection. Mice bearing LN3 and Pro5 xenograft tumors were injected with a single dose of $1 \mathrm{nmol}$ of Alexa Fluor $^{\mathrm{TM}}$ 647-labeled Apt63 or AptScr in $200 \mu \mathrm{L}$ of PBS into the tail vein. Between $10 \mathrm{~min}$ and $3.5 \mathrm{~h}$ post injection, Apt63 uptake could be detected in LN3 but not Pro5 xenografts in vivo (Fig. 3d) and in frozen sections of the same tumors (Fig. 3e). No Apt63 uptake was observed in Pro5 xenografts (Fig. 3d), suggesting that Apt63 selectively binds to and accumulates in tumors expressing its plasma membrane target. We next injected Alexa Fluor ${ }^{\mathrm{TM}}$-labeled Apt63 or AptScr into mice bearing MDA-MB-231 xenograft tumors in the mammary fat pad. Mice were monitored and euthanized at 6, 24, and $48 \mathrm{~h}$ after a single tail vein injection of Apt63 or AptScr, and frozen sections of tumors were imaged as described above. The fluorescent label was retained by Apt63-exposed MDA-MB-231 xenografts for up to $48 \mathrm{~h}$ post injection, while only background AptScr signal was detectable at any point (Fig. 3f).

In the same images, we noted an increase in nuclear fragmentation in MDA-MB-231 xenografts by $24 \mathrm{~h}$ after injection of Apt63, relative to AptScr (Fig. 3f). We further explored this by electrophoresis of tumor DNA (Fig. 3g), which revealed a distinct nucleosomal DNA cleavage pattern in Apt63-treated tumors. The cleavage pattern resembled that produced by endonuclease $\mathrm{G}$ (endoG), a nuclease that is released from the inter-mitochondrial membrane space during oxidative stress and translocates to the nucleus to initiate a caspase-independent apoptotic pathway [36, 37]. Consistent with this, Apt63-treated MDA-MB-231 tumors showed considerable nuclear endoG staining by $24 \mathrm{~h}$, while AptScr-treated tumors did not (Fig. 3h, arrowheads). These effects were not accompanied by any visible cytotoxicity toward adjacent non-tumor tissues, or any obvious adverse effects on the mouse overall conditions during the $48 \mathrm{~h}$ after injection. We interpret these results to show that Apt63 binds preferentially to breast and prostate tumor cells that express its plasma membrane target, and that Apt63 induces cell death upon binding, through a mechanism that involves release and nuclear translocation of endoG.

\section{The target of Apt63 is the beta subunit of $F_{1} F_{0}$ ATP synthase (ATP5B)}

To obtain an enriched fraction of the aptamer target on LN3 plasma membranes, we used a protocol combining a short detergent treatment with mild hypotonic lysis to segregate aptamer-bound membrane proteins from other cell components (see "Materials and methods"). Electrophoresis of this fraction yielded a single predominant protein band (Fig. 4a, 


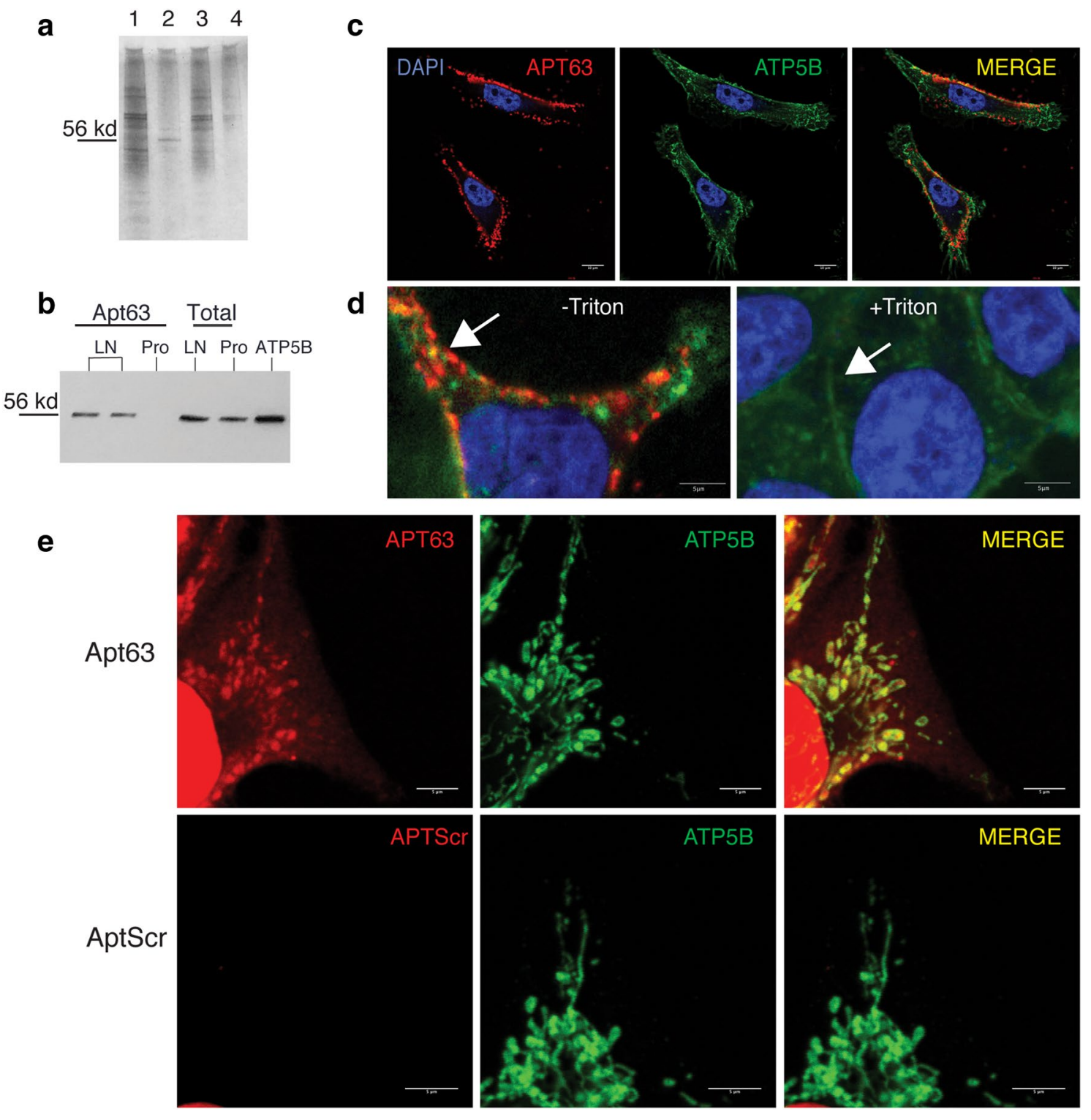

Fig. 4 Identification of Apt63 target as cell surface $\mathrm{F}_{0} \mathrm{~F}_{1}$-ATP synthase $\beta$-subunit ATP5B. a Apt63 associates with a 56kd protein in the LNCaP-LN3 plasma membrane. Representative SDS-PAGE gel of proteins immunoprecipitating with Apt63 from LN3 and Pro5 cell lines. Lane 1: LN3 whole cell lysate; Lane 2: LN3, membrane-enriched fraction; Lane 3: Pro5 total cell lysate; Lane 4: Pro5 membrane-enriched fraction. Equal amounts of protein were loaded in each lane. Bar at $56 \mathrm{kd}$ indicates the predominant LN3 aptamerassociated band subjected to mass spectroscopy as described in "Materials and methods" and Table 1. b Confirmation of $\mathrm{F}_{0} \mathrm{~F}_{1}$-ATP synthase $\beta$-subunit as aptamer target. Membrane fractions of LN3 and Pro5 prostate cells were separated as in (a). Plasma membrane-bound Apt63/target complexes (lanes 1-3), and whole cell lysates (lanes 4-5) were obtained from indicated cell lines and immunoblotted with an anti-ATP5B monoclonal antibody. A single $\sim 56 \mathrm{kd}$ protein band co-migrating with recombinant ATP5B (lane 6) is present on the membranes of LN3 (lanes 1,2) but not Pro5 cells (lane 3). Similar bands are present in whole cell lysates from both cell lines, reflecting the mitochondrial protein (lanes 4-5). c Apt63 co-localizes on plasma membrane with anti-ATP5B antibody. ATP5B antibody (green) and Apt63 (red) were bound to live LN3 cells, followed by fixation and imaging by confocal microscope. $\mathbf{d}$ The Apt63 target is extractable by detergent treatment of fixed cells. (left) Cy3-Apt63 (red) and plasma membrane marker WGA (green) were incubated with live cells followed by fixation and imaging as in (c). (right) Similarly treated cells, except that fixed slides were subjected to a short $0.05 \%$ Triton X-100 treatment. Note loss of Cy3 Apt63 signal from plasma membrane. e Apt63 stains mitochondria in permeabilized cells. Cells were fixed, then permeabilized with $0.05 \%$ Triton $\mathrm{X}-100$ and incubated with Cy3-Apt63 or Cy3-AptScr and ATP5B antibody. In these permeabilized LN3 cells, Apt63 and ATP5B antibody staining are co-localized within mitochondria. (Color figure online) 
lane 2.) A similar protein band was identified in PC-3 membrane fractions (not shown). These bands were isolated and sent for protein sequencing by mass spectrometry $(n=2$ samples from LN3, $n=1$ from PC3). The top hit in all 3 samples was ATP5B, with $28.36 \%$ of the ATP5B protein sequence detected (Table 1).

To confirm the identity of the aptamer target, we performed a western blot analysis of aptamer-associated cell membrane proteins and total cell lysates using an ATP5B antibody (Fig. 4b). A single protein band was present in Apt63-bound membrane fractions of LN3 (Fig. 4b, lanes 1,2 ) but not Pro5 cells (Fig. 4b, lane 3). The same band was readily detected in whole cell lysates of both cell lines (Fig. 4c, lanes 4, 5), and co-migrated with recombinant ATP5B protein (4c, lane 6). ATP5B antibody and Apt63 co-localized on the surface of intact LN3 cells (Fig. 4d), and within mitochondria in permeabilized LN3 cells (Fig. 4e), consistent with ectopically expressed ATP5B on the plasma membrane as a common target of the antibody and Apt63. This surface target could be extracted by detergent treatment (Fig. 4d, right), further supporting the plasma membrane location of ATP5B.

\section{Membrane ATP5B as a correlate of tumor metastasis in clinical populations}

It is not clear how ATP5B gene expression and ecto-ATP5B levels are related in any given cell type; ATP5B protein is subject to substantial post-translational and functional regulation, including plasma membrane redistribution [16, 38-41]. However, several components of the ATP synthase complex have been reported to be upregulated in cancer [40, 42, 43]. We therefore asked whether ATP5B expression was associated with cancer phenotypes in clinical populations by comparing ATP5B transcript levels in tumor vs. normal tissue in multiple prostate and breast cancer datasets. ATP5B expression was significantly higher in primary tumors when compared with normal tissues in both prostate (Fig. 5a-c) and invasive ductal breast cancer (Fig. 5d, e). In tandem with this, mean ATP copy number was significantly increased in ER-positive tumors, and in a subset of ER- (Fig. 5f), although interestingly the average copy number for ER- tumors was reduced. For both types of cancer, above-median ATP5B expression was associated with significantly decreased metastasis-free (Fig. 6a, b) and overall (Fig. 5c, d) survival. These findings are consistent with a role for ATP5B, along with other members of the complex, in supporting metastatic progression.

To characterize ATP5B protein content in human breast and prostate cancer samples, we used Apt63 to label prostate and breast cancer tissue microarrays (TMAs) representing a range of tumor grades and stages. As in the xenograft studies shown above, we confirmed that Apt63 staining co-localized with staining by a monoclonal ATP5B antibody within tumor tissue, while normal adjacent stroma was only minimally bound by either reagent (Fig. 7a). Both cytosolic and membrane staining patterns could be identified by high-resolution confocal microscopy. We observed considerable sample-to-sample heterogeneity of staining patterns across different categories of breast cancer; in some tumors, Apt63 predominantly labeled cytosolic components, including mitochondria, while in others, a clear plasma membrane pattern was identified (Fig. 7b). Staining of normal tumor-adjacent tissue was consistently weak (Fig. 7b, brackets). Using a semi-quantitative score for the presence or absence of membrane-bound ATP5B (see Online Resource 2), we saw no consistent association between the presence of ecto-ATP5B and tumor grade, PAM50 subtype, or hormone receptor status. However, plasma membrane staining of breast cancer cells by Apt63 was strongly and positively associated with tumor stage $(r=0.997, p=3.12 \mathrm{E}-03)$, appearing in 42/46 of lymph node metastases, $0 / 12$ normal breast tissue samples, and intermediate values in DCIS and invasive carcinomas (summary is presented in Table 2 and in
Table 1 Mass spectroscopy of membrane proteins immunoprecipitated from LN3 and PC-3 by Apt63. Separate experiments and MS runs were performed for each cell line. The amino acid sequence of ATP5B is shown below with mapped peptides in italics

\begin{tabular}{llllll}
\hline Cell line & Protein mass & Amino acids & $\begin{array}{l}\text { Amino acids } \\
\text { identified }\end{array}$ & $\begin{array}{l}\text { Protein coverage } \\
(\%)\end{array}$ & $\begin{array}{l}\text { Peptides } \\
\text { identi- } \\
\text { fied }\end{array}$ \\
\hline LN3 & 56524.61 & 529 & $118 \mathrm{AA}$ & 22.31 & 14 \\
PC-3 & 56524.61 & 529 & $109 \mathrm{AA}$ & 20.60 & 13 \\
& & Total & $150 \mathrm{AA}$ & 28.36 & 27 \\
\hline
\end{tabular}

MLGFVGRVAA APASGALRRL TPSASLPPAQ LLLRAAPTAV HPVRDYAAQT SPSPKAGAAT GRIVAVIGAV VDVQFDEGLP PILNALEVQG RETRLVLEVA QHLGESTVRT IAMDGTEGLV RGQKVLDSGA PIKIPVGPET LGRIMNVIGE PIDERGPIKT KQFAPIHAEA PEFMEMSVEQ EILVTGIKVV DLLAPYAKGG KIGLFGGAGV GKTVLIMELI NNVAKAHGGY SVFAGVGERT REGNDLYHEM IESGVINLKD ATSKVALVYG QMNEPPGARA RVALTGLTVA EYFRDQEGQD VLLFIDNIFR FTOAGSEVSA LLGRIPSAVG YOPTLATDMG TMOERITTTK KGSITSVQAI YVPADDLTDP APATTFAHLD ATTVLSRAIA ELGIYPAVDP LDSTSRIMDP NIVGSEHYDV ARGVQKILQD YKSLQDIIAI LGMDELSEED KLTVSRARKI QRFLSQPFQV AEVFTGHMGK LVPLKETIKG FQQILAGEYD HLPEQAFYMV GPIEEAVAKA DKLAEEHSS 
Fig. 5 ATP5B expression is increased in prostate and breast cancer vs. normal tissue. Datasets were reviewed as described in "Materials and methods." a ATP5B expression is increased in prostate adenocarcinoma compared with normal prostate tissue $(p=3.54 \mathrm{e}-4)$. $\mathrm{GS}=$ Gleason stage. Data from Vanaja et al. [74]. b ATP5B overexpression in GSE62872 prostate samples compared with normal prostate tissues $(n=424$; $p$-value $<0.0001)$. c ATP5B overexpression in TCGAPRAD samples compared with normal prostate tissues $(n=551 ; p$-value $=0.0001)$. d ATP5B overexpression in GSE109169 breast cancers compared with their paired normal breast counterparts $(n=50 ; p$-value $=0.0004)$. Gray lines link normal and tumor paired samples. e ATP5B overexpression in breast ductal cancers as compared to normal mammary tissues $(n=544$; $p$-value $=0.0005)$. Data obtained from TCGA-BRCA database. f ATP5B copy number variation in breast cancer compared to normal blood cells. Copy number is significantly increased in ER + tumors. Data from TCGA Breast 2 dataset. (Color figure online)
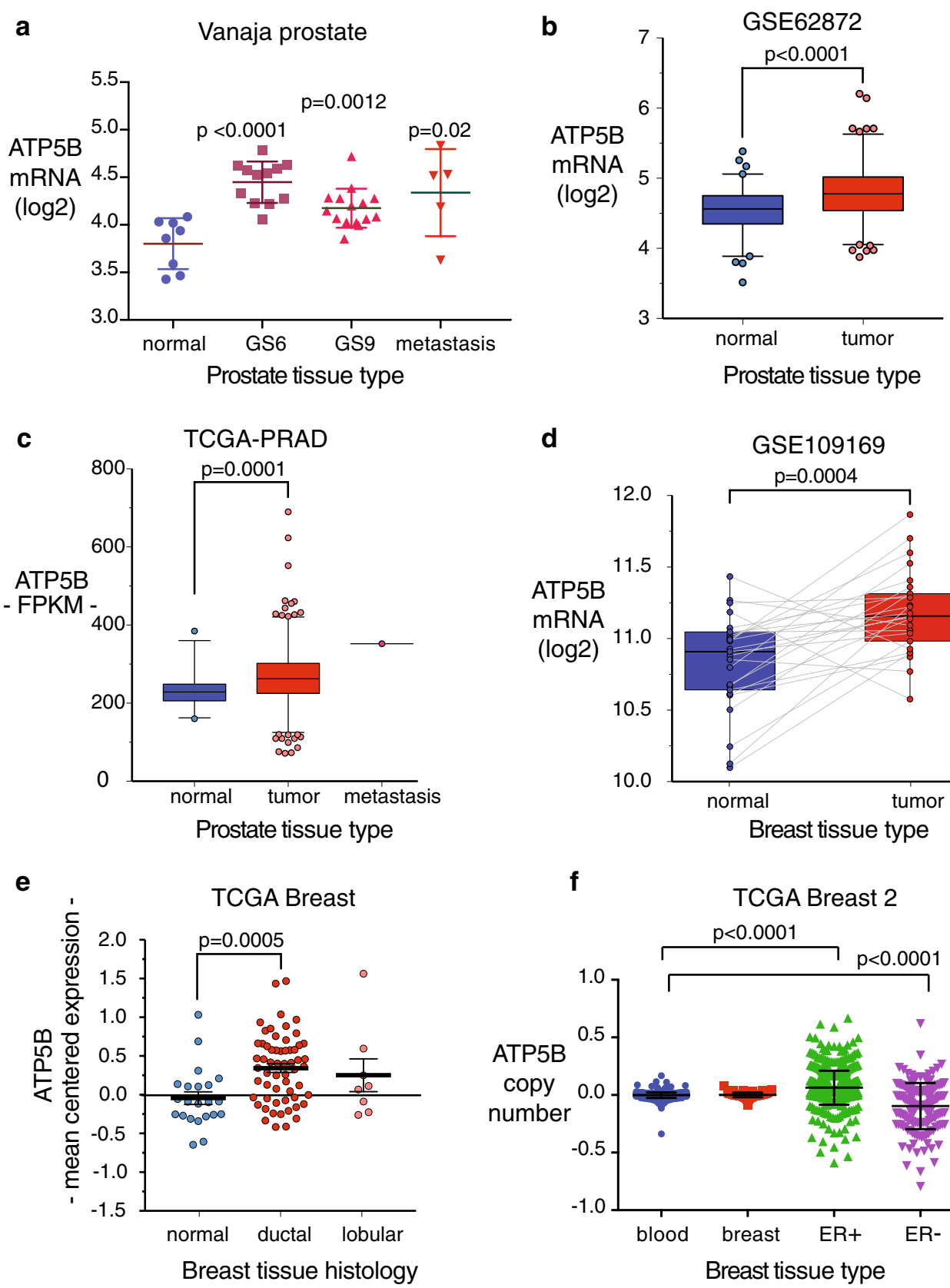
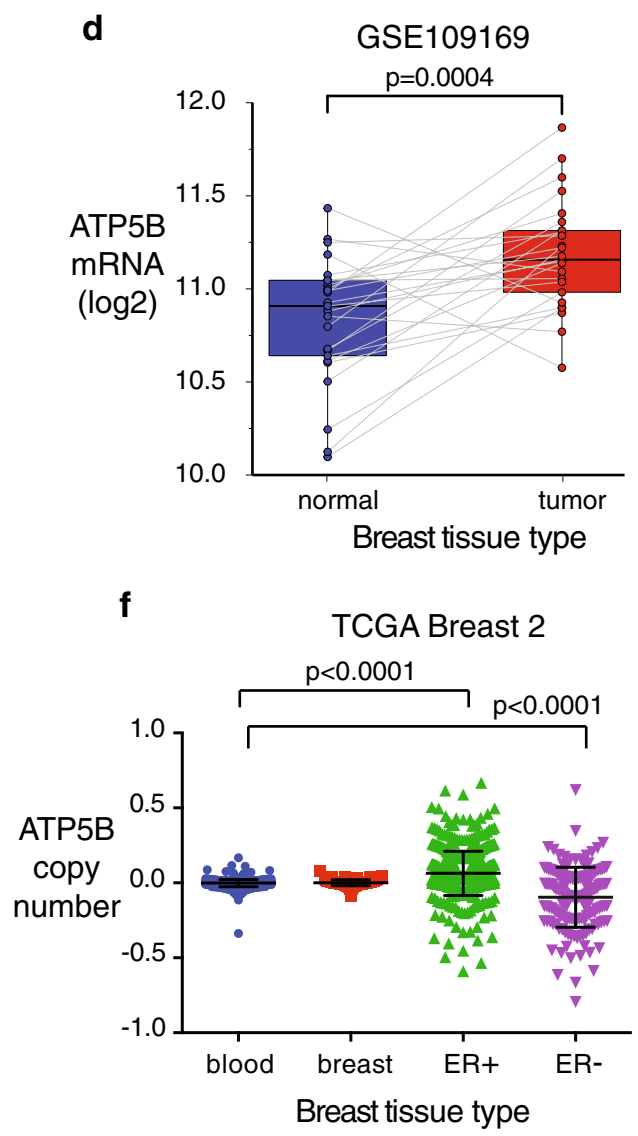

Online Resource 3). These results provide further support for a functional relationship between plasma membrane ATP5B, as indicated by binding by Apt63, and breast cancer metastasis.

\section{Discussion}

Here we show that ectopic plasma membrane ATP5B, a subunit of $\mathrm{F}_{1} \mathrm{~F}_{\mathrm{o}}$-ATP synthase, denotes a high metastasis-risk phenotype in breast and prostate cancer, and a vulnerability of cancer cells in vivo. $\mathrm{F}_{1} \mathrm{~F}_{\mathrm{o}}$ ATP synthase is a highly conserved enzyme complex residing on the inner mitochondrial membrane, where it conducts the final step in oxidative ATP production. Its 30 protein components are organized into two domains, the $\mathrm{F}_{\mathrm{o}}$ proton-translocating domain and the $\mathrm{F}_{1}$ catalytic domain $[44,45]$. Three pairs of ATP5A and ATP5B subunits form the catalytic core of $F_{1}$ in the inner mitochondrial membrane, generating ATP molecules as $\mathrm{H}+$ transits the $\mathrm{F}_{\mathrm{o}}$ pore. Defects in ATP synthase contribute to diseases including microbial infection, immune deficiency, neuropathies, obesity, diabetes, and cancer [35, 46, 47].

A plasma membrane-located ATP synthase (ecto-ATP synthase) was initially discovered as a cancer neoantigen more than 20 years ago [48]. Fully functional ATP synthase complexes have been identified on the plasma membrane of certain normal and many tumor cells, and may either 

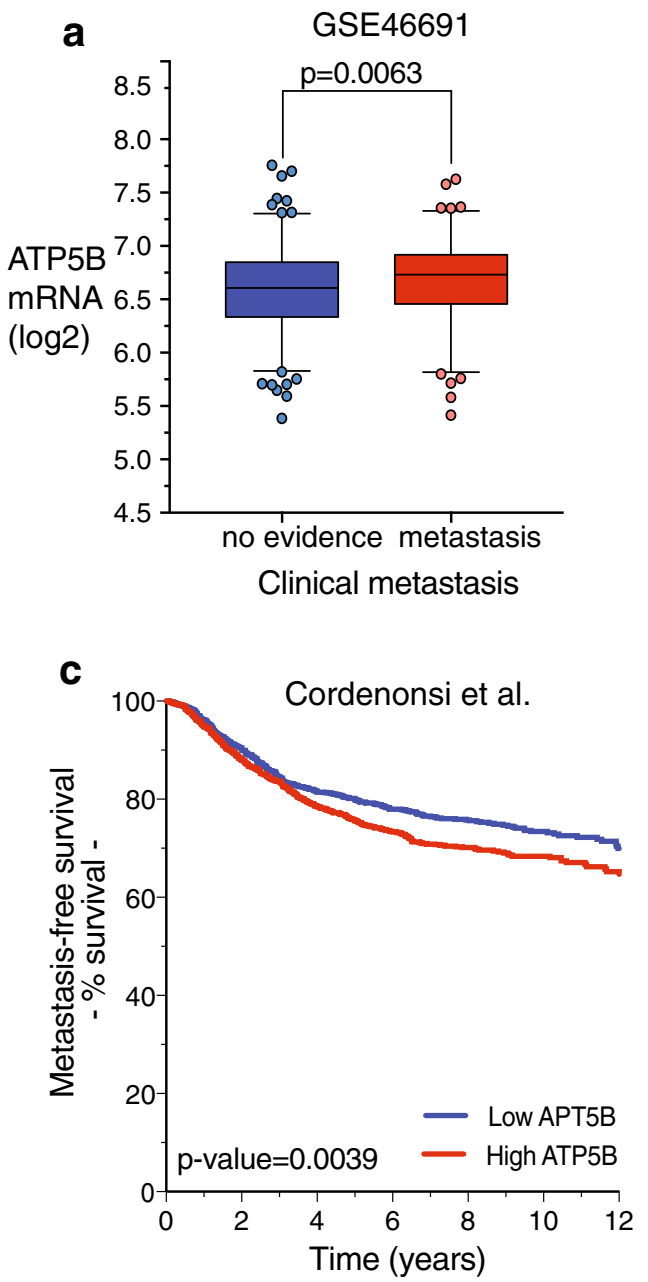

Fig. 6 Increased ATP5B expression is associated with greater risk of metastasis and reduced overall survival in prostate and breast cancer. a ATP5B expression is increased in primary prostate tumors that later metastasize. Primary prostate cancers with metastatic disease progression were compared to samples with no evidence of metastasis. Data were obtained from GSE46691 [27] $(n=545 ; p$-value $=0.0063)$. b High expression of ATP5B mRNA correlates with decreased overall survival in prostate cancer patients of the TCGA-PRAD dataset $(n=551)$. Patients with high and low ATP5B expression are shown in red and blue, respectively (see "Materials and methods"). Patients with high expression $(n=250)$ had lower overall survival probability over time $(\log$ rank $p$-value $=0.050)$. c High expression of ATP5B

hydrolyze or synthesize ATP $[10,11]$. Ecto-ATP synthase has been proposed to act as a receptor for apo-A1 and thereby to regulate HDL uptake by hepatocytes $[49,50]$ and to promote endothelial progenitor cell proliferation and angiogenesis [51]. Angiostatin has been shown to bind to ecto-ATP synthase and disrupt its ATP synthetic activity, contributing to its anti-angiogenic effects $[10,52]$. However, angiostatin is able to exert these functions through other receptors on the cell surface, including c-met [53], proteoglycan NG2 [54], and annexin II [55]. The importance
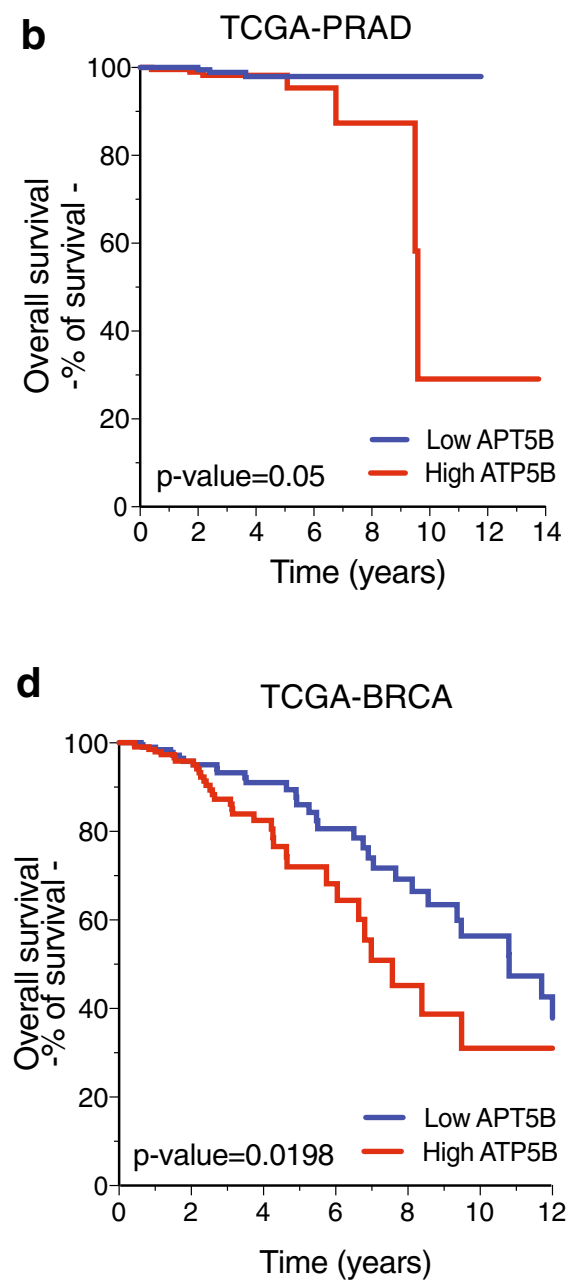

mRNA correlates with reduced metastasis-free survival in patients of a compendium of 3661 breast cancer samples. Patients with high and low ATP5B expression are shown in red and blue, respectively (see "Materials and methods"). Patients with high expression $(n=1656)$ had higher probability to develop metastasis over time (log rank $p$-value $=0.0039$ ). d High expression of ATP5B mRNA correlates with poor overall survival in breast cancer patients of the TCGABRCA dataset $(n=522)$. Patients with high and low ATP5B expression are shown in red and blue, respectively (see "Materials and methods"). Patients with high expression $(n=263)$ had lower overall survival probability over time (log rank $p$-value $=0.0198$ ). (Color figure online)

of these functions of ecto-ATP synthase in normal cells remains to be fully elucidated $[38,56]$.

ATP5B emerged in our unbiased screen as a plasma membrane feature that distinguishes the aggressive LNCaP-LN3 cell line from isogenic LNCaP and LNCaPPro5 cells, which metastasize infrequently [19]. Collectively, our data suggest that acquiring this feature may have enabled the metastatic phenotype of the LN3 subclone. Despite substantial effort, no other specific drivers of the aggressive LN3 phenotype have been identified. LN3 cells grow well in the absence of androgen, but do 
a

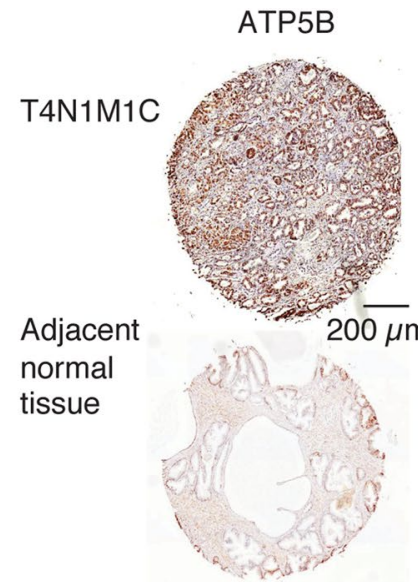

ATP5B
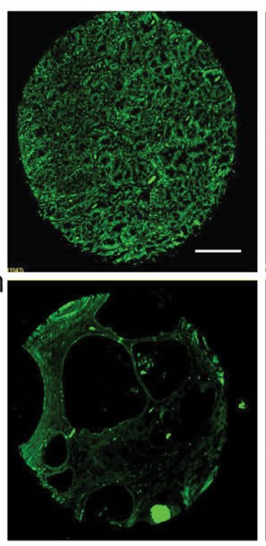

Apt63

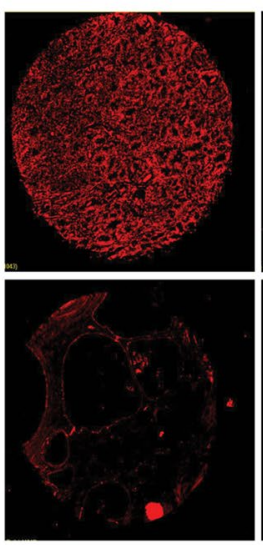

Merge

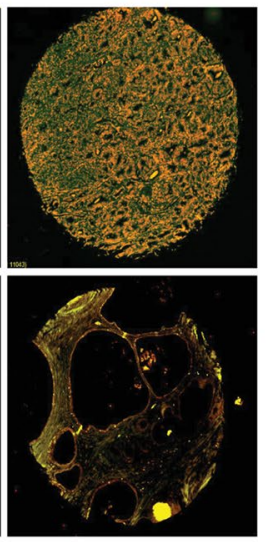

b

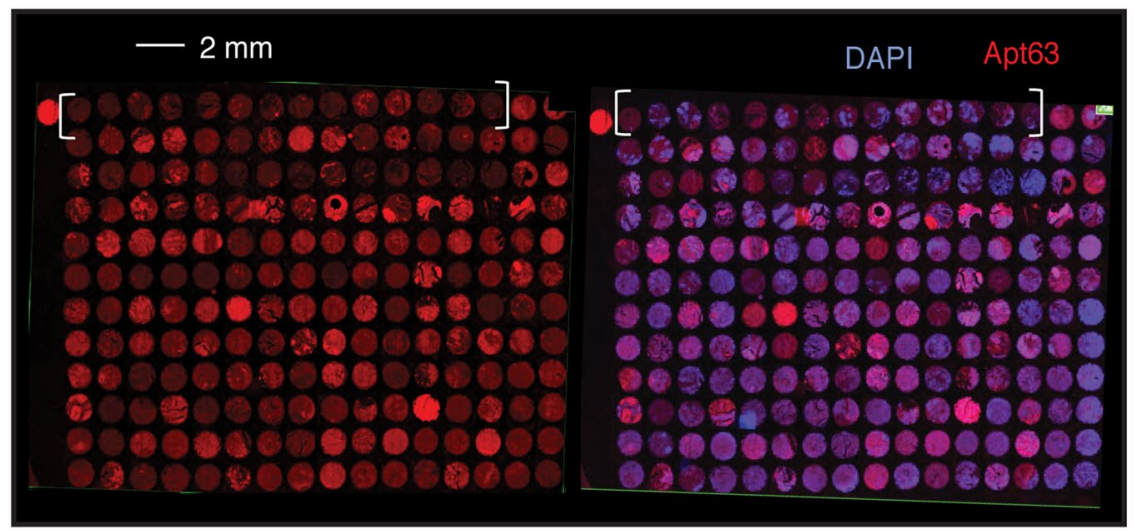

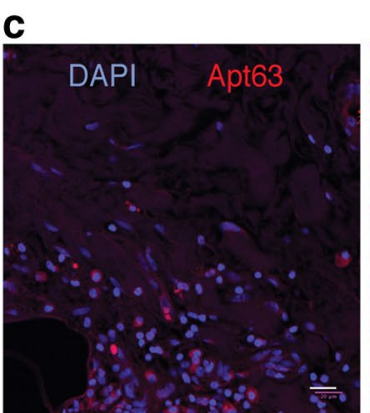

Normal stroma d

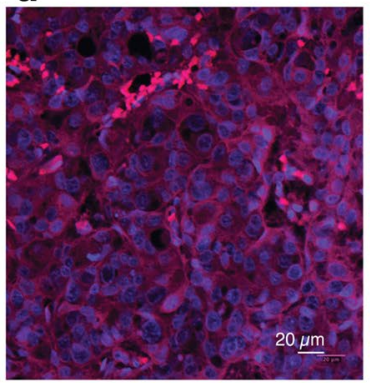

DCIS e

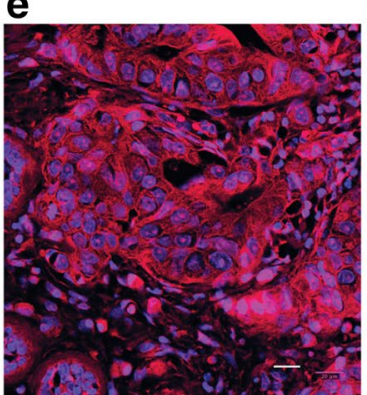

Invasive

Ductal CA $\mathbf{f}$

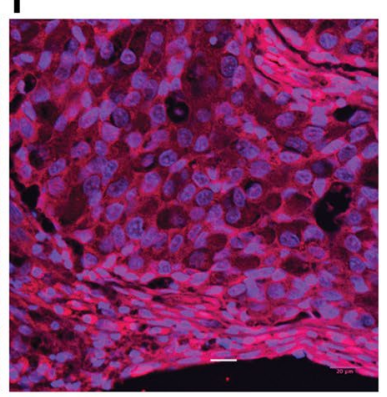

LN metastasis
Fig. 7 Apt63 binds to a subset of aggressive breast tumors and colocalizes with ATP5B. a Primary tumor core biopsies (top row) and adjacent normal tissue (bottom row) with anti-ATP5B (Abcam \#14730) using HRP (far left) or Alexa Fluor® 647 ATP5B antibodies (ab223436, ABCAM) (near left). ATP5B (assigned green color) and Cy3-Apt63 (red color) extensively co-localize both at cell membranes and in the cytosol. b Heterogeneous binding of Cy3-Apt63 to primary breast tumors and lymph node metastases. Brackets indicate normal

not have androgen receptor amplification [57]; LN3 also exhibits higher resistance to apoptosis, associated with upregulation of anti-apoptotic BCL-2 and down-regulation of BAK and BAX [57]. LN3s express higher levels of macrophage-inhibitory cytokine-1 (MIC1/GDF15) [58], the chaperone gp96 [59] and VEGFA [60], and have greater adjacent tissues in the top row. c-f Representative high-resolution confocal images of normal tissue (c), ductal carcinoma in situ (DCIS) (d), invasive ductal carcinoma (CA) (e), and lymph node metastases (LN) (f), imaged with Cy3-Apt63. A membrane staining pattern, as well as cytosolic staining, can be seen in (e) and (f). Original magnification: x20. Results shown are representative of findings in a total of 417 breast biopsies. (Color figure online)

tumor vascularity $[59,60]$ than non-metastatic LNCaP lines. No genetic differences have been shown to explain these properties, although LN3 displays unique deletions in 16q23-qter and 21q of unknown functional significance [61] and lacks a missense mutation in PlexinB1 found in parental LNCaP cells that appears to be silent [62]. 
Table 2 Tissue biopsies by pathology groups and scoring for Apt63 membrane staining

\begin{tabular}{lccc}
\hline Tissue & Apt63 positive & Total samples & Percent (\%) \\
\hline Normal breast tissue & 0 & 12 & 0.00 \\
Benign tumors & 4 & 31 & 12.90 \\
Cancer-adjacent normal breast tissue & 3 & 19 & 15.79 \\
Breast Invasive lobular CA* & 11 & 30 & 36.67 \\
Ductal CA* in situ & 10 & 22 & 45.45 \\
Breast invasive ductal CA* & 109 & 198 & 55.05 \\
Lymph node metastases & 42 & 46 & 91.30 \\
\hline
\end{tabular}

High-resolution confocal images of Cy3-Apt63 TMAs were examined for membrane-pattern staining as illustrated in Fig. 7. Apt63-specific membrane staining correlates with cancer stage, $r=0.997$ and p-value 3.12E-03(*carcinoma). Group of benign tumors represented by adenosis, hyperplasia, and fibroadenosis. Online Resource 3 contains the complete list of 416 core biopsies with stage, grade, pathology diagnosis, and Apt63 score
Previous proteomic analyses found no features distinguishing LN3 from the less-aggressive isogenic lines [63]. The same study found that endoplasmic reticulum protein ERp5 is overexpressed and displayed on the plasma membrane of both LN3 and Pro5 cells, demonstrating that cycling of intracellular peptides to the plasma membrane is not a rare event during tumorigenesis [63].

Considerable evidence links ecto-ATP synthase to aggressive cancer cell growth. Plasma membrane-associated ATP5 subunits, including ATP5B, have been correlated with moreaggressive, larger and more advanced tumors, in multiple cancers including breast, lung, and prostate [17, 42, 64]. In our breast cancer TMA analysis of Apt63 binding, including biopsies representing 416 subjects, surface ATP5B appears to define a unique subset of highly aggressive breast and prostate cancers, present on $45 \%$ of DCIS and $55 \%$ of invasive ductal carcinomas, and on almost all (91.3\%) lymph node metastases. Apt63 staining did not appear to align with tumor size or hormone receptor status, suggesting that ectoATP5B denotes an independent tumor phenotype. Surface ATP5B also appears to be important as a tumor-specific survival factor: cancer cells expressing ecto-ATP5B were rapidly killed by Apt63 binding, undergoing nuclear translocation of endonuclease $\mathrm{G}$ and DNA fragmentation, while adjacent normal tissues were spared. This selective toxicity could mean that certain breast and prostate tumors are dependent on the presence of functional ecto-ATP synthase, and points to a vulnerability not shared by non-transformed cells.

The biological importance of ecto-ATPase has been explored using a range of physiological and synthetic ligands, including angiostatin, plasminogen, monoclonal antibodies, peptides, and small molecules binding to the $\mathrm{F}_{1}$ module [12, 14, 16, 64-67]. The effects of these agents are both cell type and ligand-specific, but most reduce extracellular ATP production and cell proliferation, and some initiate programmed death. In HUVECs, which express high levels of ecto-ATP synthase, angiostatin inhibited cell proliferation and ATP production, but was not cytotoxic [10]; in A549 lung cancer cells, both angiostatin and a polyclonal antiATP5B antibody blocked ATP synthesis, induced intracellular acidification, and triggered cell death [68]. A monoclonal ATP5B antibody (McAb178-5G10) inhibited surface ATP generation and inhibited proliferation of HUVECs and MDA-MB-231 cells, but was not toxic by itself [69]. The same antibody induced apoptosis in A549 cells, accompanied by falls in extracellular ATP, intracellular $\mathrm{pH}$, and ERK and AKT phosphorylation [14]. Another monoclonal antibody against ATP5B (mAb6F2C4) inhibited extracellular ATP synthesis, proliferation, anchorage-independent colony formation of the hepatoma cell line SMMC-7721 [65]; this antibody was also able to reduce hepatoma xenograft growth in vivo. The kringle 1-5 domain of plasminogen, an ectoATP synthase ligand, triggered caspase-dependent apoptosis in endothelial cells [52]. On the other hand, binding of apolipoprotein A1 to ecto-ATP synthase promoted the survival and differentiation of endothelial progenitor cells [51]. Differences in binding sites, effects on enzyme conformation, and protein interactions of ATP synthase ligands could explain these divergent effects. Additional microenvironmental factors, including acidic extracellular $\mathrm{pH}$, may permit tumor-selective killing $[13,65]$. Further studies will be required to elucidate the specific mechanisms of Apt63induced programmed cell death in breast and prostate cancer, including effects on extracellular $\mathrm{pH}$, reactive oxygen species, and purinergic nucleotides.

The quantitative relationship between ATP5B gene expression and surface ATP synthase is undetermined and likely complex: ATP synthase subunits are encoded by both nuclear and mitochondrial genomes, and are coordinately regulated through incompletely defined translational and post-translational means [38, 39, 41, 70-72]. Nonetheless, the associations we have identified between ATP5B gene expression and both metastasis-free and overall survival in breast and prostate cancer are remarkable. It is possible that proteomic analysis would demonstrate still stronger links. Comparing the proteomes of 
MCF-7 breast cancer and a highly invasive subclone, Pan et al. [42] found that another ATP synthase subunit, ATP5A was overexpressed in the aggressive subclone. ATP5A was identified on the surface of these cells, as well as on MDAMB-231 and MDA-MB-453 breast cancer cell lines, but not on parental MCF-7 cells, or on non-tumorigenic MCF-10F breast epithelial cells [42]. In parallel, increased immunoreactive ATP5A was seen in 94\% of breast cancers, as well as in $21.2 \%$ of normal tissues. This analysis did not discriminate between membrane and cytosolic staining, but the findings are consistent with a relationship between ATP5 protein levels and appearance on the plasma membrane. Other investigators have shown that ATP5B and other subunits of ATP synthase travel on lipid rafts that may shuttle between mitochondrial and plasma membranes [16, 73]; co-localization with caveolin-1 may be required to maintain a functional surface complex in vascular endothelium [73]. It will be important to examine the extent to which ATP5B expression correlates with surface ATP5B in future clinical studies of breast cancer prognosis.

A challenge in determining whether and how cancer cells utilize ecto-ATP synthase lies in the essential role of this enzyme in normal cell metabolism, and the unclear pathway by which the complex arrives at the cell surface. Our aptamer represents a new tool that will assist in elucidating these questions. Its rapid and selective cytotoxicity to cells expressing ecto-ATP5B may help to resolve structural and mechanistic questions about the importance of this complex to cancer cell survival and metastasis. Ultimately, the ability of Apt63 ability to target this important but poorly understood tumor antigen in primary breast and prostate tumors may help both to predict and mitigate the risk of future metastasis.

Acknowledgements We are grateful to Dr. James Hnatyszyn for providing the initial impetus for this project, and to Dr. Eli Gilboa for helpful comments throughout its execution. We thank Ross Tomaino at the Harvard Taplin Mass Spectroscopy Facility for analysis of the protein samples, and Dr. Maria Boulina at the University of Miami Analytical Imaging Core Facility for assistance with confocal and in vivo imaging.

Funding This study was supported by a U.S. Department of Defense Exploration - Hypothesis Development Award \#W81XWH1210034 (to N.H.B.), by AIRC Special Program Molecular Clinical Oncology ' 5 per mille' (10016, to S.B.), by the Italian Ministry of Education, University and Research, and by the National Research Council grant Italian Epigenomics Flagship Project (Epigen) (to S.B.).

\section{Compliance with ethical standards}

Conflict of interest All authors declare that they have no conflict of interest regarding the work performed in this study.

Ethical Approval Animal studies all procedures performed in studies involving animals were conducted under the oversight of the Institutional Animal Care and Use Committee of the University of Miami using their approved protocols. All applicable international, national, and institutional guidelines for the care and use of animals were followed. Human studies for studies involving human tissue arrays and publicly accessible data, all individual samples were anonymized by the suppliers and the authors do not have access to identifying data.

Informed consent This type of study does not require formal consent and is in full compliance with institutional ethical standards.

Open Access This article is distributed under the terms of the Creative Commons Attribution 4.0 International License (http://creativeco mmons.org/licenses/by/4.0/), which permits unrestricted use, distribution, and reproduction in any medium, provided you give appropriate credit to the original author(s) and the source, provide a link to the Creative Commons license, and indicate if changes were made.

\section{References}

1. Ellis MJ, Perou CM (2013) The genomic landscape of breast cancer as a therapeutic roadmap. Cancer Discov 3:27-34. https://doi. org/10.1158/2159-8290.CD-12-0462

2. Curtis C, Shah SP, Chin SF, Turashvili G, Rueda OM, Dunning MJ, Speed D, Lynch AG, Samarajiwa S, Yuan Y, Graf S, Ha G, Haffari G, Bashashati A, Russell R, McKinney S, Langerod A, Green A, Provenzano E, Wishart G, Pinder S, Watson P, Markowetz F, Murphy L, Ellis I, Purushotham A, BorresenDale AL, Brenton JD, Tavare S, Caldas C, Aparicio S (2012) The genomic and transcriptomic architecture of 2000 breast tumours reveals novel subgroups. Nature 486:346-352. https:// doi.org/10.1038/nature10983

3. Huang KL, Li S, Mertins P, Cao S, Gunawardena HP, Ruggles KV, Mani DR, Clauser KR, Tanioka M, Usary J, Kavuri SM, Xie L, Yoon C, Qiao JW, Wrobel J, Wyczalkowski MA, ErdmannGilmore P, Snider JE, Hoog J, Singh P, Niu B, Guo Z, Sun SQ, Sanati S, Kawaler E, Wang X, Scott A, Ye K, McLellan MD, Wendl MC, Malovannaya A, Held JM, Gillette MA, Fenyo D, Kinsinger CR, Mesri M, Rodriguez H, Davies SR, Perou CM, Ma C, Reid Townsend R, Chen X, Carr SA, Ellis MJ, Ding L (2017) Proteogenomic integration reveals therapeutic targets in breast cancer xenografts. Nat Commun 8:14864. https://doi.org/10.1038/ ncomms 14864

4. Saunders EJ, Dadaev T, Leongamornlert DA, Al Olama AA, Benlloch S, Giles GG, Wiklund F, Gronberg H, Haiman CA, Schleutker J, Nordestgaard BG, Travis RC, Neal D, Pasayan N, Khaw KT, Stanford JL, Blot WJ, Thibodeau SN, Maier C, Kibel AS, Cybulski C, Cannon-Albright L, Brenner H, Park JY, Kaneva R, Batra J, Teixeira MR, Pandha H, Govindasami K, Muir K, Easton DF, Eeles RA, Kote-Jarai Z (2016) Gene and pathway level analyses of germline DNA-repair gene variants and prostate cancer susceptibility using the iCOGS-genotyping array. Br J Cancer 114:945-952. https://doi.org/10.1038/bjc.2016.50

5. Markowitz SD, Nock NL, Schmit SL, Stadler ZK, Joseph V, Zhang L, Willis JE, Scacheri P, Veigl M, Adams MD, Raskin L, Sullivan JF, Stratton K, Shia J, Ellis N, Rennert HS, Manschreck C, Li L, Offit K, Elston RC, Rennert G, Gruber SB (2016) A germline variant on chromosome $4 \mathrm{q} 31.1$ associates with susceptibility to developing colon cancer metastasis. PLoS ONE 11:e0146435. https://doi.org/10.1371/journal.pone.0146435

6. Haider MT, Taipaleenmaki H (2018) Targeting the metastatic bone microenvironment by microRNAs. Front Endocrinol 9:202. https://doi.org/10.3389/fendo.2018.00202

7. Chen W, Hoffmann AD, Liu H, Liu X (2018) Organotropism: new insights into molecular mechanisms of breast cancer metastasis. NPJ Precis Oncol 2:4. https://doi.org/10.1038/s41698-018-0047-0 
8. Wang YP, Lei QY (2018) Metabolic recoding of epigenetics in cancer. Cancer Commun (London England) 38:25. https://doi. org/10.1186/s40880-018-0302-3

9. Morita Y, Leslie M, Kameyama H, Volk DE, Tanaka T (2018) Aptamer therapeutics in cancer: current and future. Cancers (Basel) 10. https://doi.org/10.3390/cancers 10030080

10. Moser TL, Kenan DJ, Ashley TA, Roy JA, Goodman MD, Misra UK, Cheek DJ, Pizzo SV (2001) Endothelial cell surface F1-F0 ATP synthase is active in ATP synthesis and is inhibited by angiostatin. Proc Natl Acad Sci USA 98:6656-6661. https://doi. org/10.1073/pnas.131067798

11. Arakaki N, Nagao T, Niki R, Toyofuku A, Tanaka H, Kuramoto Y, Emoto Y, Shibata H, Magota K, Higuti T (2003) Possible role of cell surface H+-ATP synthase in the extracellular ATP synthesis and proliferation of human umbilical vein endothelial cells. Mol Cancer Res 1:931-939

12. Chi SL, Pizzo SV (2006) Cell surface F1Fo ATP synthase: a new paradigm? Ann Med 38:429-438. https://doi.org/10.1080/07853 890600928698

13. Mowery YM, Pizzo SV (2008) Targeting cell surface F1F0 ATP synthase in cancer therapy. Cancer Biol Ther 7:1836-1838

14. Wang WJ, Ma Z, Liu YW, He YQ, Wang YZ, Yang CX, Du Y, Zhou MQ, Gao F (2012) A monoclonal antibody (Mc178-Ab) targeted to the ecto-ATP synthase beta-subunit-induced cell apoptosis via a mechanism involving the MAPKase and Akt pathways. Clin Exp Med 12:3-12. https://doi.org/10.1007/s1023 8-011-0133-x

15. Chivasa S, Tome DF, Hamilton JM, Slabas AR (2011) Proteomic analysis of extracellular ATP-regulated proteins identifies ATP synthase beta-subunit as a novel plant cell death regulator. Mol Cell Proteom 10:M110.003905. https://doi.org/10.1074/mcp. M110.003905

16. Villa-Pulgarin JA, Gajate C, Botet J, Jimenez A, Justies N, Varela MR, Cuesta-Marban A, Muller I, Modolell M, Revuelta JL, Mollinedo F (2017) Mitochondria and lipid raft-located FOF1-ATP synthase as major therapeutic targets in the antileishmanial and anticancer activities of ether lipid edelfosine. PLoS Negl Trop Dis 11:e0005805. https://doi.org/10.1371/journal.pntd.0005805

17. Lu ZJ, Song QF, Jiang SS, Song Q, Wang W, Zhang GH, Kan B, Chen LJ, Yang JL, Luo F, Qian ZY, Wei YQ, Gou LT (2009) Identification of ATP synthase beta subunit (ATPB) on the cell surface as a non-small cell lung cancer (NSCLC) associated antigen. BMC Cancer 9:16. https://doi.org/10.1186/1471-2407-9-16

18. Dowling P, Meleady P, Dowd A, Henry M, Glynn S, Clynes M (2007) Proteomic analysis of isolated membrane fractions from superinvasive cancer cells. Biochim Biophys Acta 1774:93-101. https://doi.org/10.1016/j.bbapap.2006.09.014

19. Pettaway CA, Pathak S, Greene G, Ramirez E, Wilson MR, Killion JJ, Fidler IJ (1996) Selection of highly metastatic variants of different human prostatic carcinomas using orthotopic implantation in nude mice. Clin Cancer Res 2:1627-1636

20. Drews-Elger K, Brinkman JA, Miller P, Shah SH, Harrell JC, da Silva TG, Ao Z, Schlater A, Azzam DJ, Diehl K, Thomas D, Slingerland JM, Perou CM, Lippman ME, El-Ashry D (2014) Primary breast tumor-derived cellular models: characterization of tumorigenic, metastatic, and cancer-associated fibroblasts in dissociated tumor (DT) cultures. Breast Cancer Res Treat. https ://doi.org/10.1007/s10549-014-2887-9

21. Young L, Sung J, Stacey G, Masters JR (2010) Detection of mycoplasma in cell cultures. Nat Protoc 5:929. https://doi.org/10.1038/ nprot.2010.43

22. Roth F, De La Fuente AC, Vella JL, Zoso A, Inverardi L, Serafini P (2012) Aptamer-mediated blockade of IL4Ralpha triggers apoptosis of MDSCs and limits tumor progression. Cancer Res 72:1373-1383. https://doi.org/10.1158/0008-5472.CAN-11-2772
23. Hoinka J, Zotenka E, Friedman A, Sauna ZE, Przytycka TM (2012) Identification of sequence-structure RNA binding motifs for SELEX-derived aptamers. Bioinformatics 28(12):i215-i223. https://doi.org/10.1093/bioinformatics/bts210 doi

24. Iorns E, Drews-Elger K, Ward TM, Dean S, Clarke J, Berry D, El Ashry D, Lippman M (2012) A new mouse model for the study of human breast cancer metastasis. PLoS One 7:e47995. https:// doi.org/10.1371/journal.pone.0047995

25. Abeshouse A, Ahn J, Akbani R, Ally A, Amin S, Andry CD, Annala M, Aprikian A, Armenia J, Arora A, Auman JT (2015) The molecular taxonomy of primary prostate cancer. Cell 163:1011-1025. https://doi.org/10.1016/j.cell.2015.10.025

26. Penney KL, Sinnott JA, Tyekucheva S, Gerke T, Shui IM, Kraft P, Sesso HD, Freedman ML, Loda M, Mucci LA, Stampfer MJ (2015) Association of prostate cancer risk variants with gene expression in normal and tumor tissue. Cancer epidemiology, biomarkers \& prevention: a publication of the American Association for Cancer Research. Am Soc Prev Oncol 24:255-260. https://doi. org/10.1158/1055-9965.Epi-14-0694-t

27. Erho N, Crisan A, Vergara IA, Mitra AP, Ghadessi M, Buerki C, Bergstralh EJ, Kollmeyer T, Fink S, Haddad Z, Zimmermann B, Sierocinski T, Ballman KV, Triche TJ, Black PC, Karnes RJ, Klee G, Davicioni E, Jenkins RB (2013) Discovery and validation of a prostate cancer genomic classifier that predicts early metastasis following radical prostatectomy. PLoS One 8:e66855. https://doi.org/10.1371/journal.pone.0066855

28. Irizarry RA, Hobbs B, Collin F, Beazer-Barclay YD, Antonellis KJ, Scherf U, Speed TP (2003) Exploration, normalization, and summaries of high density oligonucleotide array probe level data. Biostatistics (Oxford England) 4:249-264. https://doi. org/10.1093/biostatistics/4.2.249

29. Chang JW, Kuo WH, Lin CM, Chen WL, Chan SH, Chiu MF, Chang IS, Jiang SS, Tsai FY, Chen CH, Huang PH, Chang KJ, Lin KT, Lin SC, Wang MY, Uen YH, Tu CW, Hou MF, Tsai SF, Shen CY, Tung SL, Wang LH (2018) Wild-type p53 upregulates an early onset breast cancer-associated gene GAS7 to suppress metastasis via GAS7-CYFIP1-mediated signaling pathway. Oncogene 37:4137-4150. https://doi.org/10.1038/ s41388-018-0253-9

30. (2012) Comprehensive molecular portraits of human breast tumours. Nature 490:61-70. https://doi.org/10.1038/nature11412

31. Cordenonsi M, Zanconato F, Azzolin L, Forcato M, Rosato A, Frasson C, Inui M, Montagner M, Parenti AR, Poletti A, Daidone MG, Dupont S, Basso G, Bicciato S, Piccolo S (2011) The Hippo transducer TAZ confers cancer stem cell-related traits on breast cancer cells. Cell 147:759-772. https://doi.org/10.1016/j. cell.2011.09.048

32. Enzo E, Santinon G, Pocaterra A, Aragona M, Bresolin S, Forcato M, Grifoni D, Pession A, Zanconato F, Guzzo G, Bicciato S, Dupont S (2015) Aerobic glycolysis tunes YAP/TAZ transcriptional activity. Embo J 34:1349-1370. https://doi.org/10.15252/ embj. 201490379

33. Adorno M, Cordenonsi M, Montagner M, Dupont S, Wong C, Hann B, Solari A, Bobisse S, Rondina MB, Guzzardo V, Parenti AR, Rosato A, Bicciato S, Balmain A, Piccolo S (2009) A Mutant-p53/Smad complex opposes p63 to empower TGFbetainduced metastasis. Cell 137:87-98. https://doi.org/10.1016/j. cell.2009.01.039

34. Sievers F, Wilm A, Dineen D, Gibson TJ, Karplus K, Li W, Lopez R, McWilliam H, Remmert M, Soding J, Thompson JD, Higgins DG (2011) Fast, scalable generation of high-quality protein multiple sequence alignments using Clustal Omega. Mol Syst Biol 7:539. https://doi.org/10.1038/msb.2011.75

35. Ahmad Z, Laughlin TF (2010) Medicinal chemistry of ATP synthase: a potential drug target of dietary polyphenols and amphibian antimicrobial peptides. Curr Med Chem 17:2822-2836 
36. Widlak P, Li LY, Wang X, Garrard WT (2001) Action of recombinant human apoptotic endonuclease G on naked DNA and chromatin substrates: cooperation with exonuclease and DNase I. J Biol Chem 276:48404-48409. https://doi.org/10.1074/jbc.M1084 61200

37. Li LY, Luo X, Wang X (2001) Endonuclease G is an apoptotic DNase when released from mitochondria. Nature 412:95-99. https ://doi.org/10.1038/35083620

38. Willers IM, Martinez-Reyes I, Martinez-Diez M, Cuezva JM (2012) miR-127-5p targets the 3'UTR of human beta-F1-ATPase mRNA and inhibits its translation. Biochim Biophys Acta 1817:838-848. https://doi.org/10.1016/j.bbabio.2012.03.005

39. Delic V, Brownlow M, Joly-Amado A, Zivkovic S, Noble K, Phan TA, Ta Y, Zhang Y, Bell SD, Kurien C, Reynes C, Morgan D, Bradshaw PC (2015) Calorie restriction does not restore brain mitochondrial function in P301L tau mice, but it does decrease mitochondrial F0F1-ATPase activity. Mol Cell Neurosci 67:4654. https://doi.org/10.1016/j.mcn.2015.06.001

40. Tanton H, Voronina S, Evans A, Armstrong J, Sutton R, Criddle DN, Haynes L, Schmid MC, Campbell F, Costello E, Tepikin AV (2018) F1F0-ATP synthase inhibitory factor 1 in the normal pancreas and in pancreatic ductal adenocarcinoma: effects on bioenergetics, invasion and proliferation. Front Physiol 9:833. https ://doi.org/10.3389/fphys.2018.00833

41. Williams EG, Wu Y, Wolski W, Kim JY, Lan J, Hasan M, Halter C, Jha P, Ryu D, Auwerx J, Aebersold R (2018) Quantifying and localizing the mitochondrial proteome across five tissues in a mouse population. Mol Cell Proteom 17:1766-1777. https://doi. org/10.1074/mcp.RA118.000554

42. Pan J, Sun LC, Tao YF, Zhou Z, Du XL, Peng L, Feng X, Wang J, Li YP, Liu L, Wu SY, Zhang YL, Hu SY, Zhao WL, Zhu XM, Lou GL, Ni J (2011) ATP synthase ecto-alpha-subunit: a novel therapeutic target for breast cancer. J Transl Med 9:211. https:// doi.org/10.1186/1479-5876-9-211

43. Xiaoyun X, Chaofei H, Weiqi Z, Chen C, Lixia L, Queping L, Cong P, Shuang Z, Juan S, Xiang C (2017) Possible involvement of F1F0-ATP synthase and intracellular ATP in keratinocyte differentiation in normal skin and skin lesions. Sci Rep 7:42672. https://doi.org/10.1038/srep42672

44. Pedersen PL, Amzel LM (1993) ATP synthases. Structure, reaction center, mechanism, and regulation of one of nature's most unique machines. J Biol Chem 268:9937-9940

45. Pedersen PL, Ko YH, Hong S (2000) ATP synthases in the year 2000: defining the different levels of mechanism and getting a grip on each. J Bioenerg Biomembr 32:423-432

46. Hong S, Pedersen PL (2008) ATP synthase and the actions of inhibitors utilized to study its roles in human health, disease, and other scientific areas. Microbiol Mol Biol Rev 72:590-641. https ://doi.org/10.1128/MMBR.00016-08

47. Gledhill JR, Montgomery MG, Leslie AG, Walker JE (2007) Mechanism of inhibition of bovine F1-ATPase by resveratrol and related polyphenols. Proc Natl Acad Sci USA 104:13632-13637. https://doi.org/10.1073/pnas.0706290104

48. Das B, Mondragon MO, Sadeghian M, Hatcher VB, Norin AJ (1994) A novel ligand in lymphocyte-mediated cytotoxicity: expression of the beta subunit of $\mathrm{H}+$ transporting ATP synthase on the surface of tumor cell lines. J Exp Med 180:273-281

49. Cavelier C, Ohnsorg PM, Rohrer L, von Eckardstein A (2012) The beta-chain of cell surface $\mathrm{F}(0) \mathrm{F}(1)$ ATPase modulates apoA-I and HDL transcytosis through aortic endothelial cells. Arterioscler Thromb Vasc Biol 32:131-139. https://doi.org/10.1161/ATVBA HA. 111.238063

50. Martinez LO, Jacquet S, Esteve JP, Rolland C, Cabezon E, Champagne E, Pineau T, Georgeaud V, Walker JE, Terce F, Collet X, Perret B, Barbaras R (2003) Ectopic beta-chain of ATP synthase is an apolipoprotein A-I receptor in hepatic HDL endocytosis. Nature 421:75-79. https://doi.org/10.1038/nature01250

51. Gonzalez-Pecchi V, Valdes S, Pons V, Honorato P, Martinez LO, Lamperti L, Aguayo C, Radojkovic C (2015) Apolipoprotein A-I enhances proliferation of human endothelial progenitor cells and promotes angiogenesis through the cell surface ATP synthase. Microvasc Res 98:9-15. https://doi.org/10.1016/j. mvr.2014.11.003

52. Veitonmaki N, Cao R, Wu LH, Moser TL, Li B, Pizzo SV, Zhivotovsky B, Cao Y (2004) Endothelial cell surface ATP synthasetriggered caspase-apoptotic pathway is essential for k1-5-induced antiangiogenesis. Cancer Res 64:3679-3686. https://doi. org/10.1158/0008-5472.CAN-03-1754

53. Wajih N, Sane DC (2003) Angiostatin selectively inhibits signaling by hepatocyte growth factor in endothelial and smooth muscle cells. Blood 101:1857-1863. https://doi.org/10.1182/blood $-2002-02-0582$

54. Goretzki L, Lombardo CR, Stallcup WB (2000) Binding of the NG2 proteoglycan to kringle domains modulates the functional properties of angiostatin and plasmin(ogen). J Biol Chem 275:28625-28633. https://doi.org/10.1074/jbc.M002290200

55. Tuszynski GP, Sharma MR, Rothman VL, Sharma MC (2002) Angiostatin binds to tyrosine kinase substrate annexin II through the lysine-binding domain in endothelial cells. Microvasc Res 64:448-462

56. Muller WEG, Ackermann M, Tolba E, Neufurth M, Ivetac I, Kokkinopoulou M, Schroder HC, Wang X (2018) Role of ATP during the initiation of microvascularization: acceleration of an autocrine sensing mechanism facilitating chemotaxis by inorganic polyphosphate. Biochem J 475:3255-3273. https://doi.org/10.1042/bcj20 180535

57. Song R, Harris LD, Pettaway CA (2010) Downmodulation of Bcl-2 sensitizes metastatic LNCaP-LN3 cells to undergo apoptosis via the intrinsic pathway. Prostate 70:571-583. https://doi. org/10.1002/pros.21091

58. Karan D, Chen SJ, Johansson SL, Singh AP, Paralkar VM, Lin MF, Batra SK (2003) Dysregulated expression of MIC-1/PDF in human prostate tumor cells. Biochem Biophys Res Commun 305:598-604

59. Glen A, Gan CS, Hamdy FC, Eaton CL, Cross SS, Catto JW, Wright PC, Rehman I (2008) iTRAQ-facilitated proteomic analysis of human prostate cancer cells identifies proteins associated with progression. J Proteome Res 7:897-907. https://doi. org/10.1021/pr070378x

60. Balbay MD, Pettaway CA, Kuniyasu H, Inoue K, Ramirez E, Li E, Fidler IJ, Dinney CP (1999) Highly metastatic human prostate cancer growing within the prostate of athymic mice overexpresses vascular endothelial growth factor. Clin Cancer Res 5:783-789

61. Chu LW, Pettaway CA, Liang JC (2001) Genetic abnormalities specifically associated with varying metastatic potential of prostate cancer cell lines as detected by comparative genomic hybridization. Cancer Genet Cytogenet 127:161-167

62. Damola A, Legendre A, Ball S, Masters JR, Williamson M (2013) Function of mutant and wild-type plexinb1 in prostate cancer cells. Prostate 73:1326-1335. https://doi.org/10.1002/pros.22678

63. Glen A, Evans CA, Gan CS, Cross SS, Hamdy FC, Gibbins J, Lippitt J, Eaton CL, Noirel J, Wright PC, Rehman I (2010) Eight-plex iTRAQ analysis of variant metastatic human prostate cancer cells identifies candidate biomarkers of progression: An exploratory study. Prostate 70:1313-1332. https://doi.org/10.1002/pros.21167

64. Li W, Li Y, Li G, Zhou Z, Chang X, Xia Y, Dong X, Liu Z, Ren B, Liu W, Li Y (2017) Ectopic expression of the ATP synthase beta subunit on the membrane of PC-3M cells supports its potential role in prostate cancer metastasis. Int J Oncol 50:1312-1320. https ://doi.org/10.3892/ijo.2017.3878 
65. Wang J, Han Y, Liang J, Cheng X, Yan L, Wang Y, Liu J, Luo G, Cheng X, Zhao L, Zhou X, Wu K, Fan D (2008) Effect of a novel inhibitory $\mathrm{mAb}$ antibody against $\beta$-subunit of F1F0 ATPase on HCC. Cancer Biol Ther 7:1829-1835. https://doi.org/10.4161/ cbt.7.11.6861

66. Chang HY, Huang HC, Huang TC, Yang PC, Wang YC, Juan HF (2012) Ectopic ATP synthase blockade suppresses lung adenocarcinoma growth by activating the unfolded protein response. Cancer Res 72:4696-4706. https://doi.org/10.1158/0008-5472. CAN-12-0567

67. Hu CW, Hsu CL, Wang YC, Ishihama Y, Ku WC, Huang HC, Juan HF (2015) Temporal phosphoproteome dynamics induced by an ATP synthase inhibitor citreoviridin. Mol Cell Proteom 14:3284-3298. https://doi.org/10.1074/mcp.M115.051383

68. Chi SL, Pizzo SV (2006) Angiostatin is directly cytotoxic to tumor cells at low extracellular $\mathrm{pH}$ : a mechanism dependent on cell surface-associated ATP synthase. Cancer Res 66(2):875-882. https ://doi.org/10.1158/0008-5472.CAN-05-2806

69. Zhang X, Gao F, Yu LL, Peng Y, Liu HH, Liu JY, Yin M, Ni J (2008) Dual functions of a monoclonal antibody against cell surface F1F0 ATP synthase on both HUVEC and tumor cells. Acta Pharmacol Sin 29:942-950. https://doi.org/10.111 1/j.1745-7254.2008.00830.x

70. Kagawa Y, Ohta S (1990) Regulation of mitochondrial ATP synthesis in mammalian cells by transcriptional control. Int J Biochem 22:219-229

71. Singh S, Khar A (2005) Differential gene expression during apoptosis induced by a serum factor: role of mitochondrial F0-F1
ATP synthase complex. Apoptosis 10:1469-1482. https://doi. org/10.1007/s10495-005-1394-1

72. Campanella M, Casswell E, Chong S, Farah Z, Wieckowski MR, Abramov AY, Tinker A, Duchen MR (2008) Regulation of mitochondrial structure and function by the F1Fo-ATPase inhibitor protein, IF1. Cell Metab 8:13-25. https://doi.org/10.1016/j. cmet.2008.06.001

73. Yamamoto K, Shimizu N, Obi S, Kumagaya S, Taketani Y, Kamiya A, Ando J (2007) Involvement of cell surface ATP synthase in flow-induced ATP release by vascular endothelial cells. Am J Physiol Heart Circ Physiol 293:H1646-H1653. https://doi. org/10.1152/ajpheart.01385.2006

74. Vanaja DK, Cheville JC, Iturria SJ, Young CY (2003) Transcriptional silencing of zinc finger protein 185 identified by expression profiling is associated with prostate cancer progression. Cancer Res 63:3877-3882

Publisher's Note Springer Nature remains neutral with regard to jurisdictional claims in published maps and institutional affiliations. 